\title{
Differential Expression of Two Glial Glutamate Transporters in the Rat Brain: Quantitative and Immunocytochemical Observations
}

\author{
Knut P. Lehre, Line M. Levy, Ole P. Ottersen, Jon Storm-Mathisen, and Niels C. Danbolt \\ Anatomical Institute, University of Oslo, Blindern, N-0317 Oslo, Norway
}

Glutamate, the major excitatory neurotransmitter in brain, is almost exclusively intracellular due to the action of the glutamate transporters in the plasma membranes. To study the localization and properties of these proteins, we have raised antibodies specifically recognizing parts of the sequences of two cloned rat glutamate transporters, GLT-1 (Pines et al., 1992) and GLAST (Storck et al., 1992). On immunoblots the antibodies against GLT-1 label a broad heterogeneous band with maximum density at around $73 \mathrm{kDa}$, while the antibody against GLAST labels a similarly broad band at around $66 \mathrm{kDa}$ in the cerebellum and a few kilodaltons lower in other brain regions. GLT-1 is expressed at the highest concentrations in the hippocampus, lateral septum, cerebral cortex, and striatum, while GLAST is preferentially expressed in the molecular layer of the cerebellum. However, both transporters are present throughout the brain, and have roughly parallel distributions in the cerebral hemispheres and brainstem. Preembedding light and electron microscopical immunocytochemistry shows that both GLT-1 and GLAST are restricted to astrocytes, which appear to express both proteins concomitantly, but in different proportions in different parts of the brain. Nerve terminal labeling was not observed. Both the amino and carboxyl terminals of GLT-1 and GLAST are located intracellularly, indicating an even number of transmembrane segments. Antibodies against a synthetic peptide corresponding to amino acid residues 2-11 of the proposed sequence of GLT-1 recognize the native rat brain GLT-1 protein, confirming that the translation initiation site is at the first ATG.

[Key words: cotransport, neurotransmitter transport, astrocytes, glutamate, anti-peptide antibodies, immunocytochemistry]

The resting extracellular concentration of the neurotransmitter (S)-glutamate has to be kept low, not only to allow for activation of glutamate receptors (Schoepp and Conn, 1993; Seeburg, 1993) to fluctuate with the release of glutamate from the nerve

\footnotetext{
Received Mar. 28, 1994; revised Aug. 12, 1994; accepted Aug. 22, 1994.

We thank Anna Torbjørg Bore, Astrid Henriette Danbolt, Beate Dihle, Gunnar Fredrik Lothe, and Tove Anita Slyngstad for technical assistance. This work was supported by Lars Fylkesakers Stiftelse, Rakel og Otto Bruuns legat, the Norwegian Research Council (as part of a EU BIOMED Concerted Action PL931248 and as Student Research Fellowships awarded to KPL and LML), Nordisk Insulinfond, and by the legacies of Nansen, Schreiner, and Langfeldt. A private donation made it economically possible to buy custom synthesized peptides

Correspondence should be addressed to Niels C. Danbolt, Anatomical Institute, University of Oslo, P.O. Box 1105, Blindern, N-0317 Oslo, Norway. Copyright (C) 1995 Society for Neuroscience $0270-6474 / 95 / 151835-19 \$ 05.00 / 0$
}

terminals, but also because excessive activation of glutamate receptors can lead to neuronal damage (Choi, 1992). The low extracellular concentration is due to the action of "high affinity" sodium dependent glutamate transporters (Balcar and Johnston, 1972; Logan and Snyder, 1972; Johnston, 1981; Kanner and Schuldiner, 1987; Nicholls and Attwell, 1990) located in the plasma membranes of both neurons (Divac et al., 1977; StormMathisen and Iversen, 1979; Taxt and Storm-Mathisen, 1984; Garthwaite and Garthwaite, 1988; Gundersen et al., 1993) and glial cells (Schousboe, 1981; Wilkin et al., 1982; Danbolt et al., 1992; Levy et al., 1993a). Several glutamate uptake systems have been described (for review, see Danbolt, 1994).

Three different eukaryotic glutamate transporters constituting a "new" protein family were cloned in 1992-GLAST (Storck et al., 1992), GLT-1 (Pines et al., 1992), and EAAC-1 (Kanai and Hediger, 1992) - but the localizations and relative distributions of the proteins have not been worked out. Although the antibody used to clone GLT has previously been used for immunocytochemistry (Danbolt et al., 1992), the possibility existed that this could detect also other members of the family. The proteins have about 55\% amino acid identity with each other and $34-39 \%$ identity with ASCT-1, a human sodium dependent neutral amino acid transporter (Arriza et al., 1993; Shafqat et al., 1993). Originally, different numbers of transmembrane $\alpha$-helices were predicted for GLAST, GLT and EAAC $(6,8$ or 9 , and 10 , respectively). However, comparison of the hydropathy plots of these proteins reveals a common pattern of hydrophobicity (Kanner, 1993; Kanai et al., 1994). Analysis with other methods is thus needed to determine the folding of the proteins.

In this study, we describe immunocytochemically and quantitatively the regional and cellular localizations of GLT and GLAST using antibodies specifically recognizing restricted parts of the sequences of the two proteins. We also address the folding of the protcins in the membranc and the location of the translation initiation site. The comparative distributions of the corresponding mRNAs have been analyzed in a separate article (Torp et al., 1994).

\section{Materials and Methods}

Materials. Bovine serum albumin (BSA), ethylene glycol-bis( $\beta$-aminoethyl ether) $N, N, N^{\prime}, N^{\prime}$-tetraacetic acid (EGTA), N-2-hydroxyethylpiperazine- $N^{\prime}$-2-ethanesulfonic acid (HEPES), keyhole limpet hemocyanin (KLH), ovalbumin, phenylmethanesulfonyl fluoride (PMSF), Triton X-100, Trizma base, and Tween 20 were from Sigma (St. Louis, MO). Sephadex G-50 fine and Protein A-Sepharose Fast Flow were from Pharmacia (Uppsala, Sweden). Freund's adjuvant was from Difco (Detroit, MI). Affi-Gel ( $N$-hydroxysuccinimide esters of cross-linked agarose) was from Bio-Rad (Richmond, CA). Nitrocellulose sheets $(0.22 \mu \mathrm{m}$ pores, $100 \%$ nitrocellulose) and electrophoresis equipment were from Hoefer Scientific Instruments (San Francisco, CA). Newborn calf serum was from GIBCO (Paisley, Scotland). Sodium dodecyl sul- 




98 ISSLITGLSG LDAKASGRLG TRAMVYYMST TIIAAVLGVI LVLAIHPGNP 101 ISSLVTGMAA LDSKASGKMG MRAVVYYMTT TIIAVVIGII IVIIIHPGKG

\section{B166-182.}

148 KLKKOLGPGK KNDEVSSLDA FLDLIRNLIP ENLVQACFQQIQTV-TKKVLV 151 T-KENMYREG KIVQVTAADA FLDLIRNMFP PNLVEACFKQFKTSYEKRSFK

B219-30

198 APPSEEANTT KAVISLLNET MNEAPEETKIVIKKGLEFKDG MNVLGLIGFF 201 VPIQANETLL GAVINNVSEA M-ETLTRIREEMVPVPGSVNG VNALGLVVES

249 IAFGIAMGKM GEQAKLMVEF FNILNEIVMK LVIMIMWYSP LGIACLICGK 251 MCFGFVIGNM KEQGQALREF FDSLNEAIMR LVAVIMWYAP LGILFLIAGK B303-314*

299 IIAIKDLEVV ARQLGMYMIT VIVGLIIHGG IFLPLIYFVV TRKNPFSFFA 301 ILEMEDMGVI GGQLAMYTVT VIVGLLIHAV IVLPLLYFLV TRKNPWVF IG

349 GIFQAWITAL GTASSAGTLP VTFRCLEDNL GIDKRVTRFV LPVGATINMD 351 GLLQALITAL GTSSSSATLP ITFKCLEENN GVDKRITRFV LPVGATINMD

B403-415 399 GTALYRAVAA IFIAOMNGVI LDGGQIVTVS LTATLASIGA ASIPSAGLVT 401 GTALYEALAA IE IAQVNNFD LNFGQIITIS ITATAASIGA AGIPQAGLVT

B493-508

449 MLLILTAVGL PTEDISLLVA VDWLLDRMRT SVNVVGDSFG AGIVYBLSKS 451 MVIVLTSVGL PTDDITLIIA VDWFLDRLRT TTNVLGDSLG AGIVEHLSRH

\section{B500-514
499 EL--DTIDSQ HRMHEDIBMT KTQSVYDDTK NHRRSNSNQC VYAAHNSVVI 501 ELKORDVRAM NSVIEENEMK KPYQLIAQDN EPEKPVADSE TKM \#\# 543 A522-541 \\ B558-68 \\ 547 DECKVTLAAN GKSADCSVRE EPWKREK \# \# 573}

Figure 1. Diagram of the amino acid sequences of GLT $(B)$ and GLAST $(A)$. The oligopeptide parts of the sequences that have been synthesized and used to raise antibodies are shown in boldface, and the amino acid residue numbers are given, the preceding letter $(B$ or $A)$ being aligned with the first amino acid of the peptide. Peptides from putative extracellular loops are indicated $(*)$. \#\#, The number of the last amino acid of the protein. The putative membrane spanning regions are underlined.

fate (SDS) of high purity ( $>99 \% \mathrm{C}_{12}$ alkyl sulfate) was from Pierce (Rockford, IL). $N, N^{\prime}$-methylene-bisacrylamide, acrylamide, ammonium persulfate, TEMED, alkaline phosphatase-conjugated anti-rabbit IgG and alkaline phosphatase substrates (nitroblue tetrazolium and 5-bromo4-chloro-3-indolyl phosphate) were from Promega (Madison, WI). Standard proteins for sodium dodecyl sulfate-polyacrylamide gel electrophoresis (SDS-PAGE) (Rainbow markers), biotinylated donkey anti-rabbit Ig, biotinylated sheep anti-mouse Ig, streptavidin-biotinylated horseradish peroxidase complex, X-ray film (Hyperfilm-MP), intensifier screens, and iodinated Bolton and Hunter reagent in dry benzene (with charcoal trap, $2000 \mathrm{Ci} / \mathrm{mmol}$ ) were from Amersham Corporation (Buckinghamshire, UK). Glutaraldehyde, EM grade, was from TAAB (Reading, UK) and Durcupan ACM from Fluka (Buchs, Switzerland). Other reagents were analytical grade.

The peptides, except C510-524, were obtained as C-terminal amides $80-95 \%$ pure (as determined by HPLC) either from the Centre of Biotechnology (Oslo, Norway) or Multiple Peptide Systems (San Diego, CA). All peptides representing parts of GLAST are referred to by capital letter " $\mathrm{A}$ " followed by numbers indicating the corresponding amino acid residues in the sequence (Storck et al., 1992). The sequences are given in parentheses using the one-letter amino acid code: A3-14 (KSNGEEPRMGSR), A494-508 (VEHLSRHELKNRDVE), and A522-541 (PYQLIAQDNEPEKPVADSET). Similarly, peptides synthesized from the sequence of the glutamate transporter GLT-1 (Pines et al., 1992) are referred to by the letter " $B$ " followed by the amino acid residue numbers: B2-11 (ASTEGANNMP), B12-26 (KQVEVRMHDSHLSSE), B19-34 (HDSHLSSEEPKHRNLG), B69-83 (PIHPDVVMLIAFPGD), B166-182 (DAFLDLIRNLFPENLVQ), B219230 (NEAPEETKIVIK), B303-314 (KDLEVVARQLGM), B403-415

\section{P T H X S CB P T H X S C B}

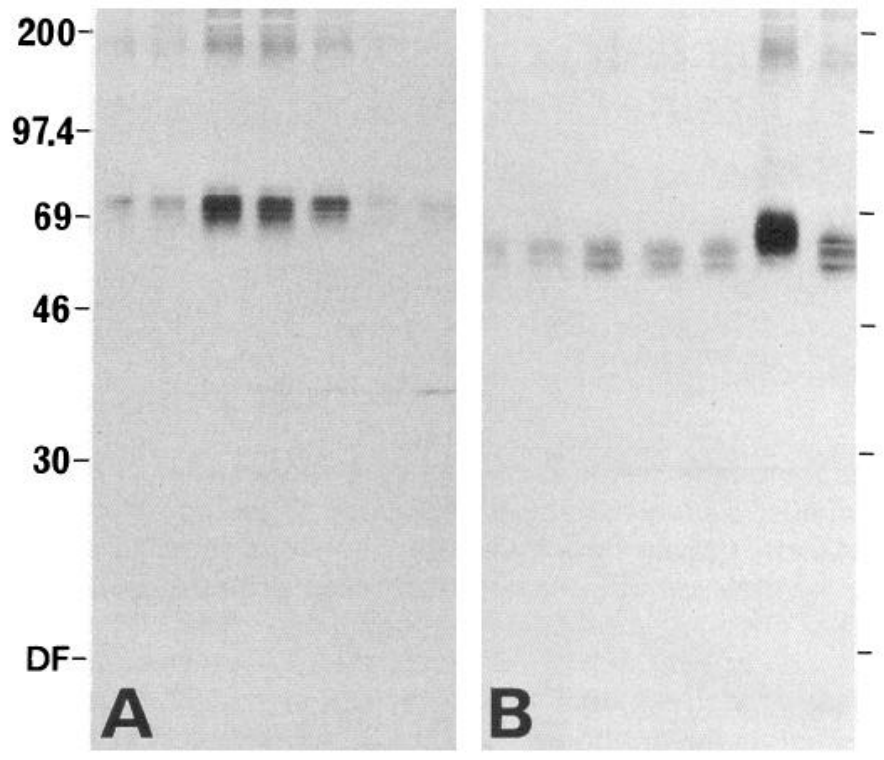

Figure 2. Immunoblot (Western blot) of crude SDS extracts of brain areas subjected to SDS-PAGE $(2 \mu \mathrm{g}$ protein/lane $)$ and reacted with GLT antibody anti-B493 $(A)$ or GLAST antibody anti-A522 $(B)$ followed by alkaline phosphatase conjugated secondary antibodies. Anti-B12 and MAb $9 \mathrm{C} 4$ showed the same staining pattern shown in $A$. Note that the GLT and GLAST antibodies stain different bands. The bands are broad and appear somewhat heterogeneous. The staining at the top of the gels represents dimers and higher aggregates. The GLAST band is at a slightly higher apparent molecular mass in cerebellum than in other parts of the brain. Regions dissected: $P$, pons/medulla oblongata; $T$, thalamus/hypothalamus; $H$, hippocampal formation; $X$, neocortex; $S$, corpus striatum; $C$, cerebellum; $B$, bulbus olfactorius. Molecular mass markers are indicated $(\mathrm{kDa})$.

(YEAVAAIFIAQMNK), B493-508 (YHLSKSELDTIDSQHR), B500514 (LDTIDSQHRMHEDIE), B517-525 (KTQSVYDDT), B518-536 (TQSVYDDTKNHRESNSNQC), and B558-568 (KSADCSVEEEP). The peptide B517-525 was not used for immunization, only for spot tests. Peptides from the glutamate transporter EAAC-1 (Kanai and Hediger, 1992) are referred to by "C": C468-482 (KELEQMDVSSEVNIV), C486-499 (ALESATLDNEDSDT), and C510-524 (VDKSDTISFTQTSQF).

Coupling of synthetic peptides to carrier protein. The peptides were coupled (Briand et al., 1985) to carrier protein (BSA, ovalbumin, or $\mathrm{KLH}$ ) in the following way: an equal volume $2 \%$ glutaraldehyde was added to a solution of carrier protein $(1 \mathrm{mg} / \mathrm{ml})$ and peptide $(1 \mathrm{mg} / \mathrm{ml})$ in $0.15 \mathrm{M} \mathrm{NaCl}$ and $0.1 \mathrm{M} \mathrm{Na}$-HEPES $\mathrm{pH} 7.4$. After incubation $(60 \mathrm{~min}$, $4^{\circ} \mathrm{C}$, continuous stirring sodium borohydride $(10 \mathrm{mg} / \mathrm{ml})$ was added. The mixture was incubated $\left(60 \mathrm{~min}, 4^{\circ} \mathrm{C}\right)$ and gel filtered on Sephadex G-50 equilibrated with $50 \mathrm{~mm}$ sodium phosphate buffer $(\mathrm{NaPi}) \mathrm{pH} 7.4$.

The peptide-ovalbumin conjugates were used for testing of antisera, not for immunization. About $0.1 \mu \mathrm{l}$ of the above gel filtered conjugate solution was applied in each spot on a strip of nitrocellulose membrane. The nitrocellulose strips were subsequently developed as described for "immunostaining of blots" below. It was found (data not shown) that some of the unconjugated peptides bound poorly to nitrocellulose giving false negative results. This was avoided by spotting peptide-protein conjugates (carrier protein different from that used for immunization) instead of free peptides.

Immunization. The above conjugates $(0.1 \mathrm{ml})$ were mixed with 0.3 $\mathrm{ml}$ water, emulsified with $0.5 \mathrm{ml}$ Freund's complete adjuvant and injected into female Chinchilla rabbits $(\mathrm{Chbb}: \mathrm{CH})$. The rabbits were reimmunized every month as above, but using Freund's incomplete adjuvant. On days 8,12 , and 16 after each immunization, the rabbits were bled.

Immobilization of carrier protein and peptides on agarose. Carrier protein was dissolved in water and dialyzed against $10 \mathrm{~mm}$ Na-HEPES pH 7.4 over night. Affi-Gel 15 was coupled $\left(4^{\circ} \mathrm{C}\right)$ to saturation with carrier protein using $0.1 \mathrm{M} \mathrm{Na-HEPES} \mathrm{(pH} \mathrm{7.5)} \mathrm{as} \mathrm{coupling} \mathrm{buffer} \mathrm{and}$ 

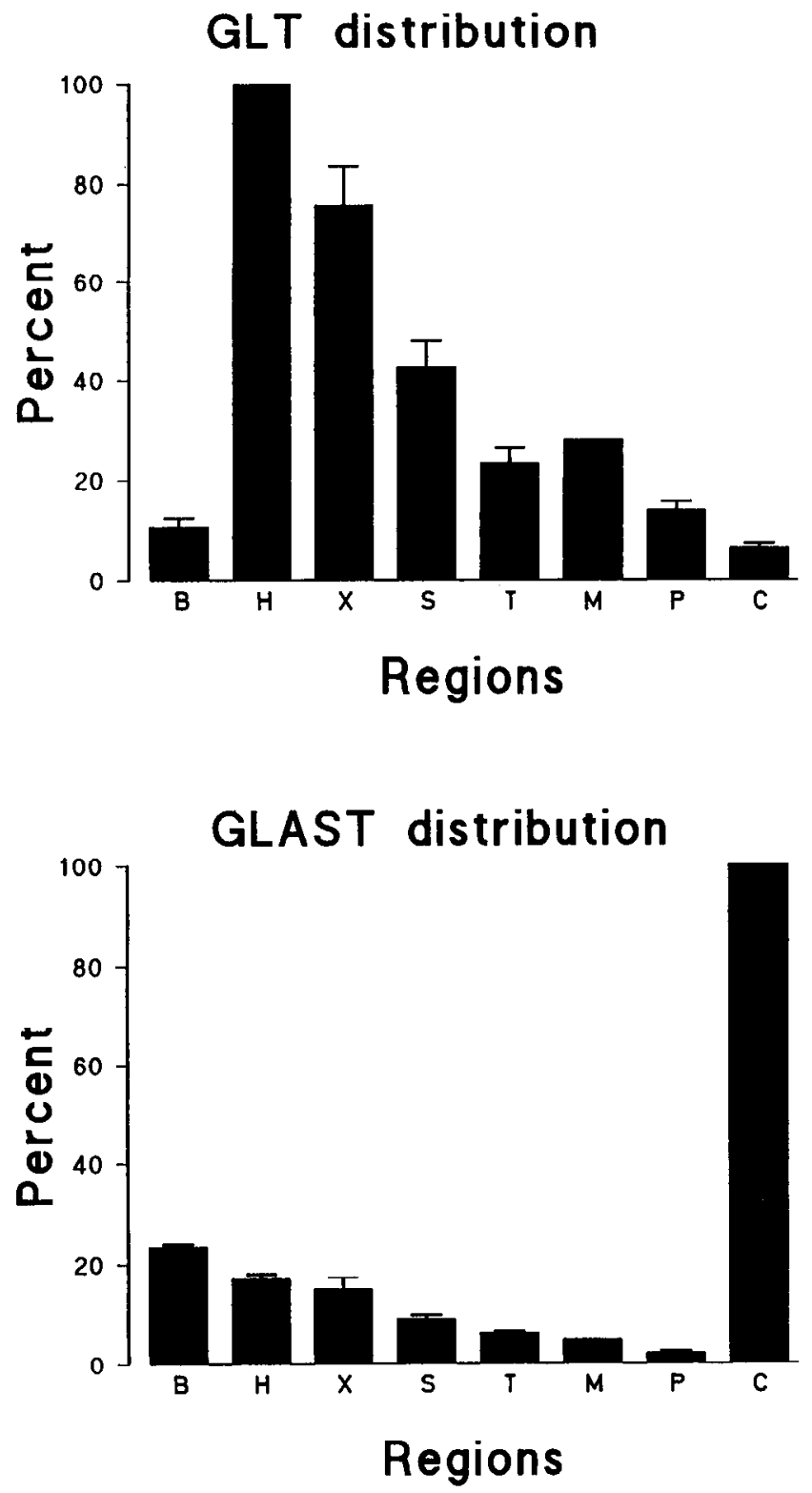

Figure 3. Quantitative distribution of GLT and GLAST in different regions of rat brain. Immunoblots with $20 \mu \mathrm{g}$ protein/lane were reacted with antibodies to peptides B12 (top) and A522 (bottom) followed by ${ }^{125} \mathrm{I}$-protein $\mathrm{A}$. The bands were located by exposure to $\mathrm{x}$-ray filmi and the amounts of radioactivity in the main bands determined by gammacounting (see Materials and Methods). The results represent mean \pm SEM of three sets of immunoblots. The rank orders of GLT and of GLAST immunoreactivities were the same in all three experiments. The values obtained from the region with highest immunoreactivity (cerebellum in the case of GLAST and hippocampus in the case of GLT) were arbitrarily defined as $100 \%$, and the values from the other regions were expressed as percentage of this highest value. Note that the same rank orders were observed in Figure 2, and that the distribution of GLT and GLAST are similar except for regions $C$ and $B$. Regions: $B$, bulbus olfactorius; $H$, hippocampal formation; $X$, neocortex; $S$, corpus striatum; $T$, thalamus/hypothalamus; $M$, mesencephalon; $P$, pons/medulla oblongata; $C$, cerebellum.

following the manufacturer's instructions. After coupling the gel was washed with $\mathrm{NaPi}$ and incubated ( $2 \mathrm{hr}$, end-over-end mixing) in several volumes of $2 \%$ glutaraldehyde freshly diluted in $0.1 \mathrm{M} \mathrm{NaPi} \mathrm{pH} \mathrm{7.4.}$ Free aldehyde was removed by washing with $10 \mathrm{~mm} \mathrm{NaPi}$ and double bonds reduced by incubation ( $1 \mathrm{hr}$ or over night) with $\left(1 \%\right.$ w/v) $\mathrm{NaBH}_{4}$ (in a flask big enough to contain the foam). After washing of the gel in $\mathrm{NaPi}$, normal rabbit serum (with $1 \mathrm{~mm}$ PMSF) was added to the gel in order to saturate unspecific protein binding sites. The gel was incubated ( $1 \mathrm{hr}$ or over night), washed with 3 volumes of $0.2 \mathrm{M}$ glycine$\mathrm{HCl}$ buffer ( $\mathrm{pH} 2.5$ ) containing $0.15 \mathrm{M} \mathrm{NaCl}$, and then neutralized with $2 \mathrm{M}$ Tris- $\mathrm{HCl} \mathrm{pH} 8.5$.

Peptide ( $1 \mathrm{mg}$ ) was dissolved in Na-HEPES buffer $\mathrm{pH} 8$ and coupled to Affi-Gel $15(10 \mathrm{ml}$ gel $)$ following the manufacturer's instructions. $N, N$-dimethylformamide was added if the peptides were poorly soluble.

Antibody purification. Monoclonal antibodies (Levy et al., 1993a) and polyclonal antibodies (Danbolt et al., 1992) raised against the purified $73 \mathrm{kDa}$ glutamate transporter (Danbolt et al., 1990) were from the same purified batches as those previously published.

The purification of antibodies directed against peptides was performed at room temperature. Because the peptides used for immunization were coupled to carrier protein, antibodies were generated that recognize the carrier protein and aldehyde treated proteins in general. The latter, in particular, had to be removed before application to aldehyde fixed tissuc (sce immunocytochemistry below) as they gave background and cell nucleus staining.

The antibodies against the peptides A3-14, A522-541, B12-26, B 19-34, B500-514 and B518-536 and B493-508 were first purified by absorption against glutaraldehyde treated carrier protein. Crude undiluted serum $(5 \mathrm{ml})$ with $1 \mathrm{~mm}$ PMSF was applied (at a flow rate of 1 $\mathrm{ml} / \mathrm{min})$ on the $(50 \mathrm{ml})$ glutaraldehyde-carrier protein column equilibrated with starting buffer consisting of $50 \mathrm{~mm}$ Tris- $\mathrm{HCl} \mathrm{pH} 7.4,0.3 \mathrm{M}$ $\mathrm{NaCl}, 1 \mathrm{~mm}$ sodium ethylenediamine tetraacetate (EDTA), Tween 20 $(0.5 \mu \mathrm{l} / \mathrm{ml})$, and $\mathrm{NaN}_{3}(1 \mathrm{mg} / \mathrm{ml})$. The run was monitored using an ultraviolet detector (Pharmacia UV-1). The protein peak was collected and the column was regenerated by washing with 2 column volumes of $0.1 \mathrm{M}$ glycine- $\mathrm{HCl} \mathrm{pH} 2.5$, neutralized with $5 \mathrm{ml}$ of $2 \mathrm{M}$ Tris- $\mathrm{HCl} \mathrm{pH}$ 8.5 , and then equilibrated with starting buffer.

IgG was isolated using a $6 \mathrm{ml}$ of protein A-Sepharose column equilibrated with the above starting buffer. The above (dilute) absorbed serum (from several runs of the above column) was applied (1-3 $\mathrm{ml} / \mathrm{min}$ ). After washing with starting buffer, the IgG was eluted with $0.2 \mathrm{M} \mathrm{Na}$ citrate $\mathrm{pH} 3.7$, neutralized with $2 \mathrm{M}$ Na-HEPES $\mathrm{pH} 9$ and applied on a column carrying immobilized peptide. After washing with the above starting buffer, the anti-peptide antibodies were eluted with $0.2 \mathrm{M}$ glycine- $\mathrm{HCl}(\mathrm{pH} 2.5$ ) with $150 \mathrm{mM} \mathrm{NaCl}$ and neutralized with $2 \mathrm{M} \mathrm{Na-}$ HEPES pH 9 . BSA $(1 \mathrm{mg} / \mathrm{ml})$ and $\mathrm{NaN}_{3}(1 \mathrm{mg} / \mathrm{ml})$ were added to stabilize the antibodies.

This purification procedure was automated using Pharmacia FPLCcomponents (valves, pumps, UV-detector, pHI-detector, fraction collector and columns) controlled by a PC-based system designed for the purpose (by K.P.L.). The removal of unwanted antibodies was very efficient. No aldehyde reactivity could be detected in the purified antibodies.

For the first testing of a large number of antisera, a cheaper and quicker large scale purification procedure was developed by changing the order of the columns: the antisera against A494-508, B2-11, B69$83, \mathrm{~B} 219-230, \mathrm{~B} 166-182, \mathrm{~B} 303-314$, and B558-568 were first affinity purified on a column with immobilized peptide and then tested on immunoblots. As the affinity purification removes most, but not all contaminating antibodies, promising antibodies were further purified by absorption against glutaraldehyde treated immobilized carrier protein and concentrated on protein A-Sepharose. After protein determination, PMSF (1 mM), EDTA (5 mM), and BSA $(10 \mathrm{mg} / \mathrm{ml})$ were added. The antibodies were stored at $+4^{\circ} \mathrm{C}$.

Preparation of SDS extracts. SDS extracts from whole rat brains or specific regions were prepared by homogenizing and solubilizing the tissue in $20 \mathrm{~mm}$ or $50 \mathrm{~mm}$ NaPi pH 7.4 with SDS $(10 \mathrm{mg} / \mathrm{ml})$ and 1 mM PMSF, and removing unsolubilized material by centrifugation $\left(39,000 \times g, 10 \mathrm{~min}, 20^{\circ} \mathrm{C}\right)$.

Electrophoresis and blotting. SDS-PAGE was done as described (Laemmli, 1970). The gels were $0.75 \mathrm{~mm}$ thick, had $25 \mathrm{~mm}$ deep wells, $20 \mathrm{~mm}$ stacking gel (4\% acrylamide) and $11 \mathrm{~cm}$ separating gels (10 or $7.5 \%$ acrylamide). The gels were run slowly (overnight) at constant current starting at $30 \mathrm{~V}$. After electrophoresis the proteins were either silver stained (Danbolt et al., 1990) or electroblotted (100 V, $2 \mathrm{hr}$ ) onto nitrocellulose membranes as described (Towbin, 1979).

Immunostaining of blots. This was done at room temperature. For nonradioactive labeling, the blots were briefly rinsed $(1 \times 30 \mathrm{~s})$ in 10 $\mathrm{mm}$ Tris- $\mathrm{HCl} \mathrm{pH} 8.0,150 \mathrm{~mm} \mathrm{NaCl}, 8 \mathrm{mM} \mathrm{NaN}_{3}, 0.05 \%(\mathrm{v} / \mathrm{v})$ Tween 20 (TBST). After blocking ( $60 \mathrm{~min})$ of unspecific binding sites with blocking solution (BSA $10 \mathrm{mg} / \mathrm{ml}$ in TBST), the nitrocellulose was incubated (over night) with antibodies in new blocking solution. Anti- 

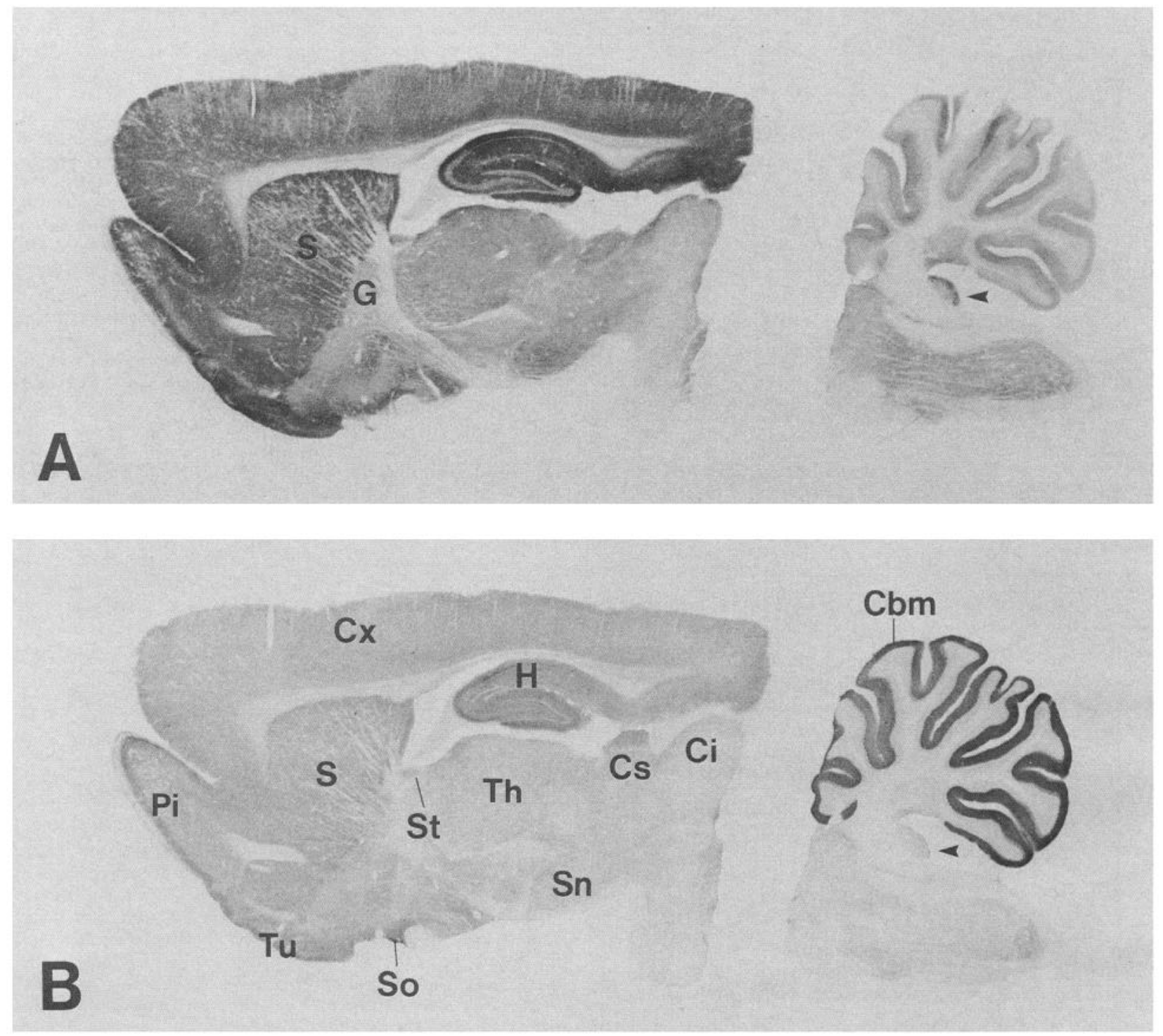

Figure 4. Immunocytochemical localization of GLT $(A, C)$ and GLAST $(B, D)$ in closely spaced parasagittal sections incubated with antibodies to the peptides B12 $(A, C)$ and A522 $(B, D)$. Perfusion fixed with a mixture of $4 \%$ formaldehyde, $0.2 \%$ picric acid, $0.05 \%$ glutaraldehyde, sections processed with antibodies in the presence of Triton X-100, and the antibody concentrations $(0.1 \mu \mathrm{g} / \mathrm{ml})$ chosen to give similar maximum staining intensities for GLT and GLAST. Note that both GLT and GLAST occur in all regions, but at varying concentrations, and are low in white matter. GLAST is concentrated in the cerebellar molecular layer $(\mathrm{Cbm})$, and less so in a few forebrain regions $(\mathrm{So}, \mathrm{Ls}, \mathrm{Pi})$. GLT is high in telencephalic areas $(H, C x, P i, T u, S)$. Abbreviations: $B u$, olfactory bulb; $C b m$, cerebellar molecular layer; $C i$ and $C s$, inferior and superior colliculi; $C x$, cerebral cortex; $G$, globus pallidus; $H$, hippocampal formation; $L s$, lateral septum; $P i$, piriform cortex; $P n$, pontine nuclei; $S$, corpus striatum; $S n$, substantia nigra; So, supraoptic nucleus; St, stria terminalis; Th, thalamus; Tu, olfactory tubercle. Arrowhead, molecular layer of dorsal cochlear nucleus; *, missing part of vibratome section; arrow, blood vessel. Scale bar, $2 \mathrm{~mm}$.

peptide antibodies were used at $200 \mathrm{ng} / \mathrm{ml}$ when not stated otherwise. The polyclonal antibodies (Danbolt et al., 1992) raised against the 73 $\mathrm{kDa}$ purified protein (Danbolt et al., 1990) were used at $50 \mathrm{ng} / \mathrm{ml}$, while the 9C4 monoclonal IgM antibodies (Levy et al., 1993a) were used at $100 \mathrm{ng} / \mathrm{ml}$. After washing with TBST $(1 \times 1 \mathrm{~min}$ followed by $3 \times 10$ $\mathrm{min})$, the blots were incubated $(1 \mathrm{hr})$ with alkaline phosphatase conjugated anti-rabbit IgG (200 ng/ml; Promega, Madison, WI) or anti-mouse Ig $(200 \mathrm{ng} / \mathrm{ml}$; Promega, Madison, WI) in blocking solution. After washing in TBST $(4 \times 10 \mathrm{~min})$, the nitrocellulose was blotted damp on absorbent paper and, without drying, quickly immersed in alkaline phosphatase substrate buffer.

For radioactive labeling, the blots were washed $(1 \times 1 \mathrm{~min})$ with 140 $\mathrm{mM} \mathrm{NaCl}, 2.7 \mathrm{mM} \mathrm{KCl}, 1.5 \mathrm{~mm} \mathrm{KH} \mathrm{PO}_{4}$ and $8.1 \mathrm{mM} \mathrm{Na}_{2} \mathrm{HPO}_{4}$, pH 7.4 (PBS) and blocked $(60 \mathrm{~min})$ with gelatin $(10 \mathrm{mg} / \mathrm{ml})$ in PBS. After incubation (over night) with antibody (same concentrations as above), the blots were washed $(3 \times 10 \mathrm{~min})$ with PBS with Tween $20(2 \mu \mathrm{l} / \mathrm{ml})$, reblocked
(15 min) with gelatin $(2.5 \mathrm{mg} / \mathrm{ml})$ in PBS with Tween 20 incubated $(90$ $\mathrm{min})$ with iodinated protein $\mathrm{A}(3000 \mathrm{cpm} / \mu \mathrm{l})$ in PBS with Tween 20 and gelatin $(2.5 \mathrm{mg} / \mathrm{ml})$, washed $(4 \times 10 \mathrm{~min})$ with PBS with Tween 20 , dried, and autoradiographed at $-75^{\circ} \mathrm{C}$ using $\mathrm{x}$-ray film in a cassette with intensifier screen. After development, the film was aligned under the nitrocellulose blots on a light box so that the dark bands on the film could be seen through the nitrocellulose. The bands were subsequently cut out of the blot and the radioactivity determined in a Packard gamma-counter (Minaxi $\gamma$ Auto-gamma 5000 series). Similar sized pieces of nitrocellulose (outside the area that had been in contact with the polyacrylamide gel during the blotting) were used to determine the background. The radioactive labeling of the glutamate transporter bands were linear with the amount of crude SDS-extracted brain proteins in the range $1-30 \mu \mathrm{g}$ pr. polyacrylamide gel lane. Similarly, when crude SDS-extracted liver and brain proteins were mixed to give $25 \mu \mathrm{g}$ total protein in each lane, the labeling was proportional to the amount of brain protein in the sample. 



Figure 4. Continued.

Iodination of protein $A$. This was done by reacting protein A to a (commercially obtained) reagent consisting of a preiodinated tyrosine residue connected to an $\mathrm{N}$-hydroxysuccinimide ester which binds to amino groups (Bolton and Hunter, 1973).

Purification of glutamate transporter proteins. The different fractions containing purified glutamate transporters were from the same experiments as have been published (Danbolt et al., 1992). The purification procedure (Danbolt et al., 1990, 1992) consisted of solubilization of brain membranes with the detergent CHAPS (Hjelmeland, 1980) and separation of the proteins by affinity chromatography on wheat germ agglutinin (lectin) followed first by fractionation on a hydroxylapatite column and finally on a DEAE-cellulose ion-exchange column. The various fractions from the purification procedure were immunoblotted with anti-GLT and anti-GLAST antibodies.

Protein determination. Protein was determined (Lowry et al., 1951) with BSA as standard. Protein in purified antibody solutions was determined spectrophotometrically at $280 \mathrm{~nm}$ using bovine IgG as standard.

Immunocytochemistry. Rats (Wistar strain, Møllegaard Hansen, Denmark) were given a lethal dose of pentobarbital $(100 \mathrm{mg} / \mathrm{kg})$. When deeply anesthetized, but before cessation of spontaneous respiration, they were perfused through the left ventricle-aorta with fixative in 0.1 M NaPi pH 7.4 (15 min, room temperature), preceded by a brief flush $\left(10-15 \mathrm{sec}, 25 \mathrm{ml}, 4^{\circ} \mathrm{C}\right)$ of dextran $70(\mathrm{MW} 70000 ; 40 \mathrm{mg} / \mathrm{ml})$ in the same buffer without fixative. The right atrium was cut open at the start of the perfusion. The perfusion liquids were delivered by a peristaltic pump at $50 \mathrm{ml} / \mathrm{min}$. The brains were postfixed $(2-3 \mathrm{hr})$ in the same fixative. The tissue was stored at $4^{\circ} \mathrm{C}$ in a storage solution consisting of 1 part fixative and 9 parts $0.1 \mathrm{M} \mathrm{NaPi}$ until it was processed for preembedding light and electron microscopic immunocytochemistry. Four different fixatives were used: formaldehyde (4\%) alone, a glutaraldehyde/formaldehyde mixture $(2.5 \% / 1 \%)$, formaldehyde/glutaraldehyde $(4 \% / 0.02 \%)$, or a formaldehyde/picric acid/glutaraldehyde $(4 \% /$ $0.2 \% / 0.05 \%$ ) fixative described previously (Somogyi and Takagi, 1982). The aldehydes were freshly added, formaldehyde freshly depolymerized from paraformaldehyde.

Vibratome sections $\left(40 \mu \mathrm{m}\right.$ thick) were cut $\left(4-10^{\circ} \mathrm{C}\right)$ and stored $\left(4^{\circ} \mathrm{C}\right.$, $12 \mathrm{hr}$ to 3 weeks) in $0.1 \mathrm{M} \mathrm{NaPi}$ with $\mathrm{NaN}_{3}(0.2-1 \mathrm{mg} / \mathrm{ml})$. Then the sections were rinsed in $0.1 \mathrm{M} \mathrm{NaPi}$, incubated $(30 \mathrm{~min})$ in $1 \mathrm{M}$ ethanolamine with $0.1 \mathrm{M} \mathrm{NaPi}$, washed $(3 \times 1 \mathrm{~min})$ in buffer $\mathrm{A}(0.135 \mathrm{M}$ $\mathrm{NaCl}, 0.01 \mathrm{M} \mathrm{NaPi})$, incubated in buffer $\mathrm{B}(0.3 \mathrm{M} \mathrm{NaCl}, 0.1 \mathrm{M}$ Tris$\mathrm{HCl} \mathrm{pH} \mathrm{7.4)} \mathrm{with} 10 \%(\mathrm{v} / \mathrm{v})$ newborn calf serum and $\mathrm{NaN}_{3}(1 \mathrm{mg} / \mathrm{ml})$, and then incubated $\left(12-48 \mathrm{hr}, 4^{\circ} \mathrm{C}\right.$ or room temperature) with anti-peptide antibodies $(0.03-10 \mu \mathrm{g} / \mathrm{ml})$, anti-73 $\mathrm{kDa}$ antibodies $(0.3-2.5 \mu \mathrm{g} /$ $\mathrm{ml})$ or $9 \mathrm{C} 4$ antibodies $(12-120 \mu \mathrm{g} / \mathrm{ml})$ in the same solution. The sections were washed $(3 \times 1 \mathrm{~min}$ and $2 \times 10-20 \mathrm{~min})$ in buffer $\mathrm{C}$ (buffer B with $1 \%$ newborn calf serum without $\mathrm{NaN}_{3}$ ), incubated $(1 \mathrm{hr})$ with biotinylated donkey anti-rabbit Ig (1:100) or biotinylated sheep anti- 

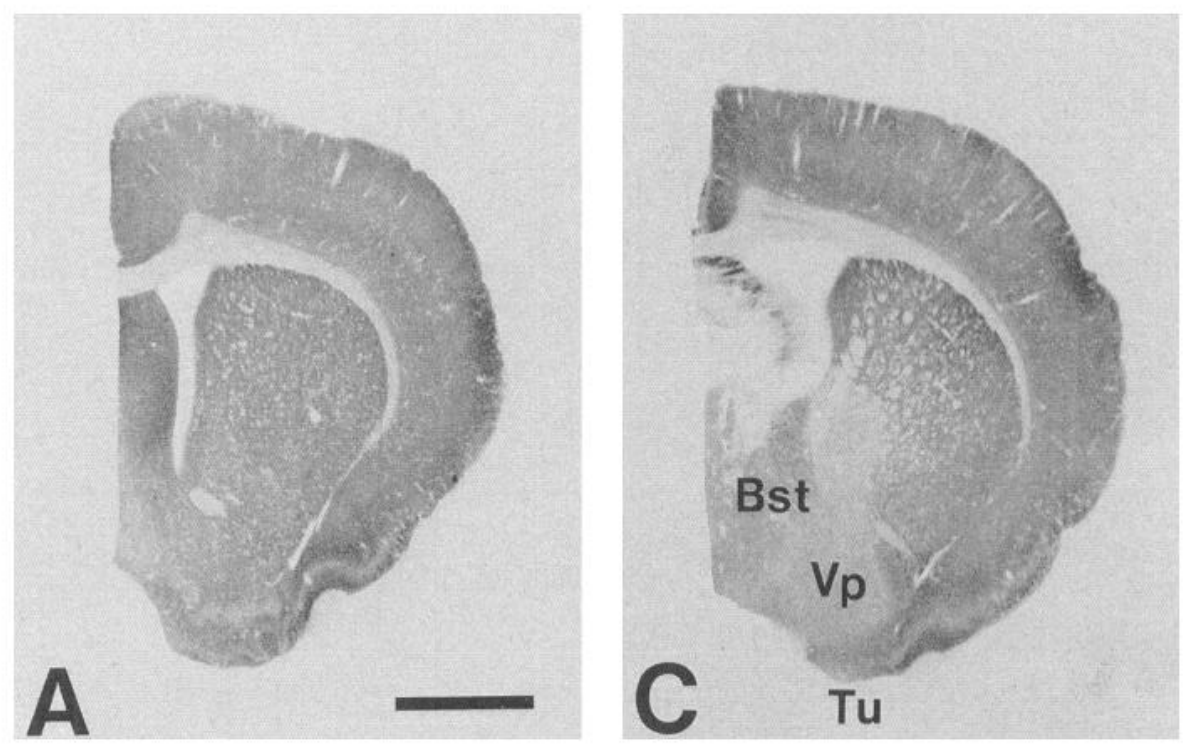

Figure 5. Immunocytochemical localization of GLT $(A, C, E, G)$ and GLAST $(B, D, F, H)$ in closely spaced serial coronal sections of rat brain; same conditions as Figure 4. Note the differences pointed out in Figure 4, a difference between the $L g d$ and $L g v$ is visible for GLT, but not for GLAST. Both GLT and GLAST appear higher dorsally than ventrally in Me. Some slight apparent differences, such as between cortical regions are not generally valid. Abbreviations of regions (in addition to those shown in Fig. 4): Bst, bed nucleus of the stria terminalis; $L g d$ and $L g v$, dorsal and ventral parts of LGN; $L h$, lateral hypothalamus; Lot, lateral olfactory tract; $\mathrm{Me}$, medial amygdaloid nucleus; $P c o$, posteromedial cortical amygdaloid nucleus; $R f$, rhinal fissure; $V p$, ventral pallidum. Scale bar, $2 \mathrm{~mm}$.
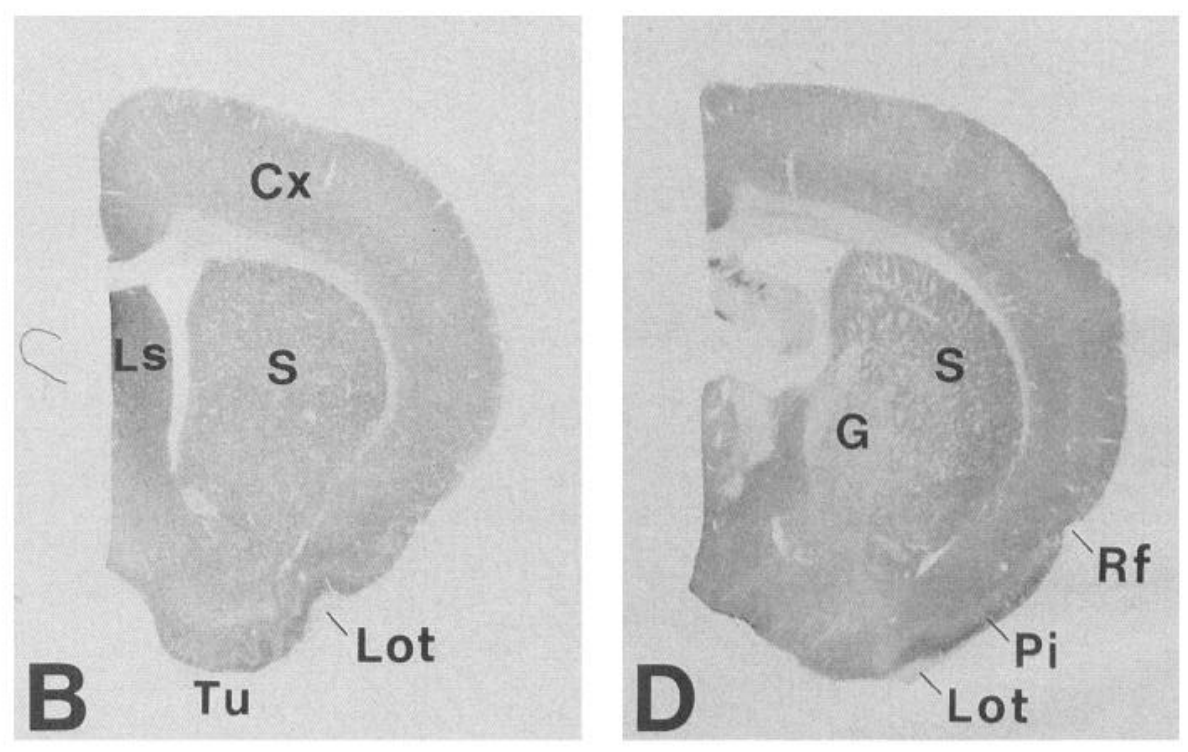

mouse $\operatorname{Ig}(1: 100$ or $1: 33)$ in buffer $\mathrm{C}$, washed $(3 \times 1$ min and $2 \times 10$ $20 \mathrm{~min}$ ) in buffer $\mathrm{C}$, incubated $(1 \mathrm{hr})$ with streptavidin-biotinylated horseradish peroxidase complex in buffer $\mathrm{C}$, and washed $(3 \times 1 \mathrm{~min}$ and $2 \times 10-20 \mathrm{~min})$ in buffer $\mathrm{C}$. Then the sections were washed $(3 \times$ $1 \mathrm{~min}$ ) in buffer $\mathrm{A}$, incubated for $6 \mathrm{~min}$ in $0.1 \mathrm{M} \mathrm{NaPi}$ with $\mathrm{H}_{2} \mathrm{O}_{2}(0.1$ $\mathrm{mg} / \mathrm{ml})$ and diaminobenzidine $(0.5 \mathrm{mg} / \mathrm{ml})$ after $6 \mathrm{~min}$ of preincubation in $\mathrm{NaPi} /$ diaminobenzidine without $\mathrm{H}_{2} \mathrm{O}_{2}$, and finally the reaction was stopped with $0.1 \mathrm{NaPi}(2 \times 3 \mathrm{~min})$. Triton $\mathrm{X}-100(0.5 \%)$ was included only when stated. For light microscopy, vibratome sections were mounted in glycerol-gelatin. Brain areas were identified referring to the atlas of Paxinos and Watson (1982). For electron microscopy, the sections were treated with $\mathrm{OsO}_{4}(30-45 \mathrm{~min}, 10 \mathrm{mg} / \mathrm{ml}$ in $0.1 \mathrm{M} \mathrm{NaPi})$, washed $(3 \times 1 \mathrm{~min})$ in $0.1 \mathrm{M} \mathrm{NaPi}$, dehydrated in graded ethanols $(50 \%, 70 \%$, $80 \%, 96 \% 1 \times 5 \mathrm{~min}$ and $100 \% 3 \times 10 \mathrm{~min}$ ) and propylene oxide $(2$ $\times 5 \mathrm{~min}$ ), and embedded in Durcupan ACM. Ultrathin sections were cut at right angles to the thick $(40 \mu \mathrm{m})$ ones in order to be able to study the parts of the tissue that had been in immediate contact with the reagents. The sections were contrasted $(10 \mathrm{mg} / \mathrm{ml}$ uranyl acetate $10-15$ $\mathrm{min}, 3 \mathrm{mg} / \mathrm{ml} \mathrm{Pb}$-citrate 1-2 $\mathrm{min}$ ), or left uncontrasted, and examined in a Phillips CM10 electron microscope. For control, primary antibodies were substituted by preimmune IgG, immune IgG freed of specific IgG by immunosorption with immobilized peptide or preabsorbed with the corresponding free peptide. As a positive control for the electron microscopic appearance of extracellular staining, the primary and second- ary antibodies were replaced by biotinylated wheat germ agglutinin (1$25 \mu \mathrm{g} / \mathrm{ml}$ ).

Postembedding Glu. Some ultrathin sections were processed for simultaneous demonstration of glutamate-like immunoreactivity by the postembedding immunogold method (Storm-Mathisen and Ottersen 1990 , and references therein). Antiserum "03 Glu," solid-phase-absorbed as described to remove antibodies reacting with other aldehydefixed amino acids and with aldehyde treated protein, was used at a dilution of 1:1000 (for details and extensive testing, see Davanger et al., 1994). As a precaution against traces of cross-reactivity the dilution medium contained $100 \mu \mathrm{M}$ glutamine and $100 \mu \mathrm{M}(S)$-aspartate previously reacted with glutaraldehyde. Addition of $300 \mu \mathrm{M}$ glutaraldehydereacted $(S)$-glutamate abolished immunoreactivity (similar sections, same antibodies), that is, gave tissue particle densities similar to that over empty resin in blood vessel lumina.

\section{Results}

\section{Production and characterization of antibodies}

Antibodies were raised to 10-20-mer oligopeptide sequences of the transporters (Fig. 1). All the rabbits produced antibodies against the peptides, except B403-415, as assayed by dot blot. The B2 rabbit gave a weak response after the fourth immuni- 

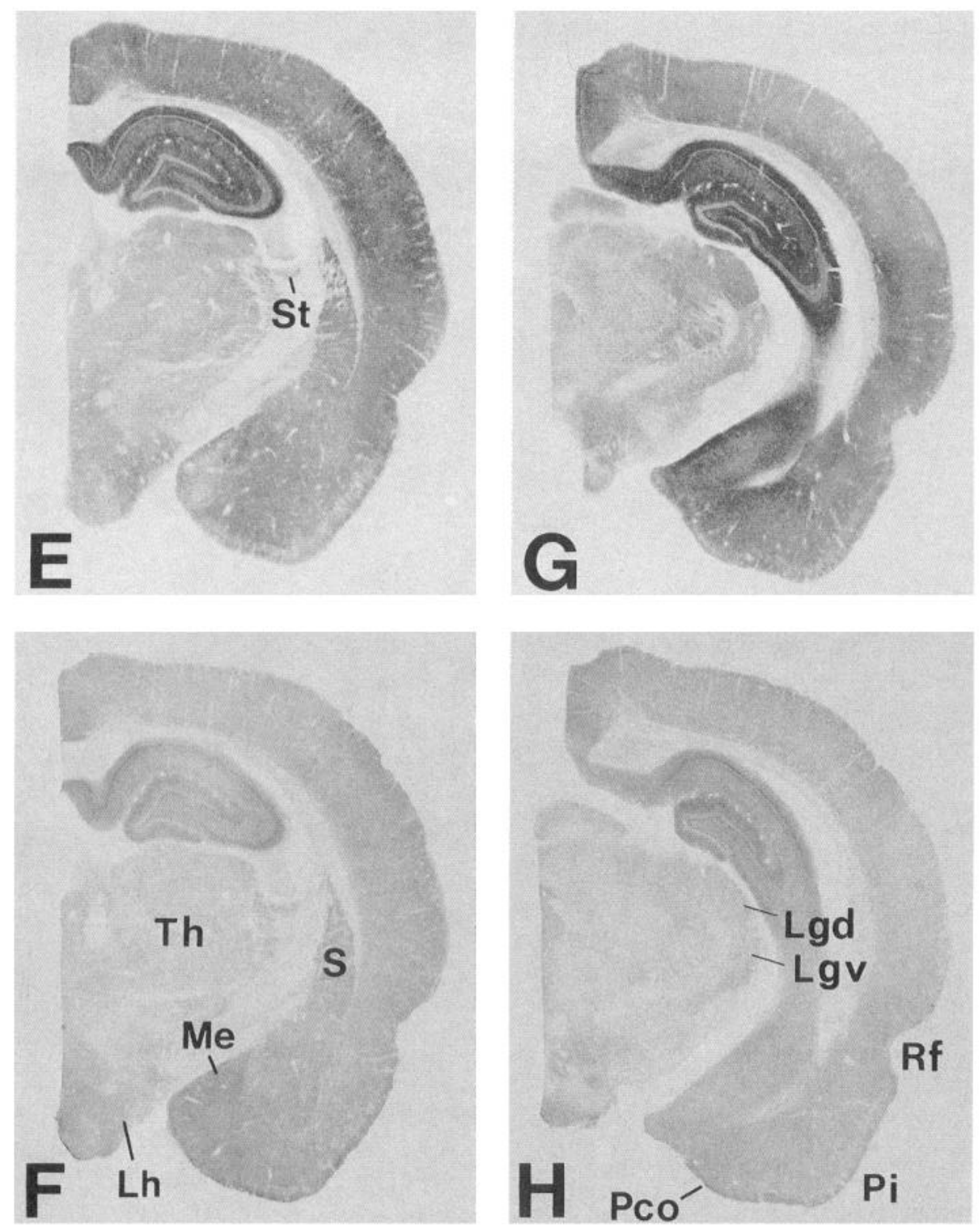

Figure 5. Continued.

zation. The other rabbits responded after the second immunization. The antisera reacted strongly with the corresponding peptides even when diluted several thousand fold. On immunoblots, however, strong and specific reactions with brain proteins of the right molecular masses were seen only with antibodies to the peptides A522-541, B12-26, and B493-508. This study is based mainly on these three antibodies. The antibodies against B2-11, B19-34, B500-514, and B518-536 did label the right band, but were obtained in small quantities. Only a few sections have been stained with these antibodies, but the results obtained were identical to those obtained with the above anti-GLT antibodies as well as with polyclonal (anti$73 \mathrm{kDa}$ ) and monoclonal $(9 \mathrm{C} 4)$ antibodies raised against the purified glutamate transporter (Danbolt et al., 1992; Levy et al., 1993a).

The antibodies against A494-508, B69-83, B219-230, B166-182, and B303-314 did not label the expected band. The anti-A3 and anti-B558 antibodies labeled predominantly the expected bands, but there were also some weaker labeling of several additional bands. In tissue sections, the immuno- cytochemical picture obtained with anti-A3 was identical to that obtained with anti-A522, both at the light- and electron microscopic level.

It was attempted to raise antibodies to the putative neuronal transporter EAAC-1 from rabbit (Kanai and Hediger, 1992) by immunizing both sheep and rabbits with peptides corresponding to the C-terminal part of this molecule. In all cases antibodies were obtained that specifically reacted with the peptide, but on immunoblots of rat brain and rabbit brain and intestine they showed no band or multiple bands.

Spot tests revealed that the 9C4 monoclonal antibody (Levy et al., 1993a) not only reacted with B518-536, but also with B517-525 indicating that the epitope is between residues 518 and 525 . The polyclonal anti-73 $\mathrm{kDa}$ antibodies (Danbolt et al., 1992) raised against a purified glutamate transporter (Danbolt et al., 1990) have been shown (Levy et al., 1993a) to react strongly with the B493-508 peptide, and at higher concentrations, reactivity is also seen with B518-536, B12-26, and B500-514 (in that order of decreasing strength). This IgG also reacts with other unknown epitopes as absorption against the above peptides 

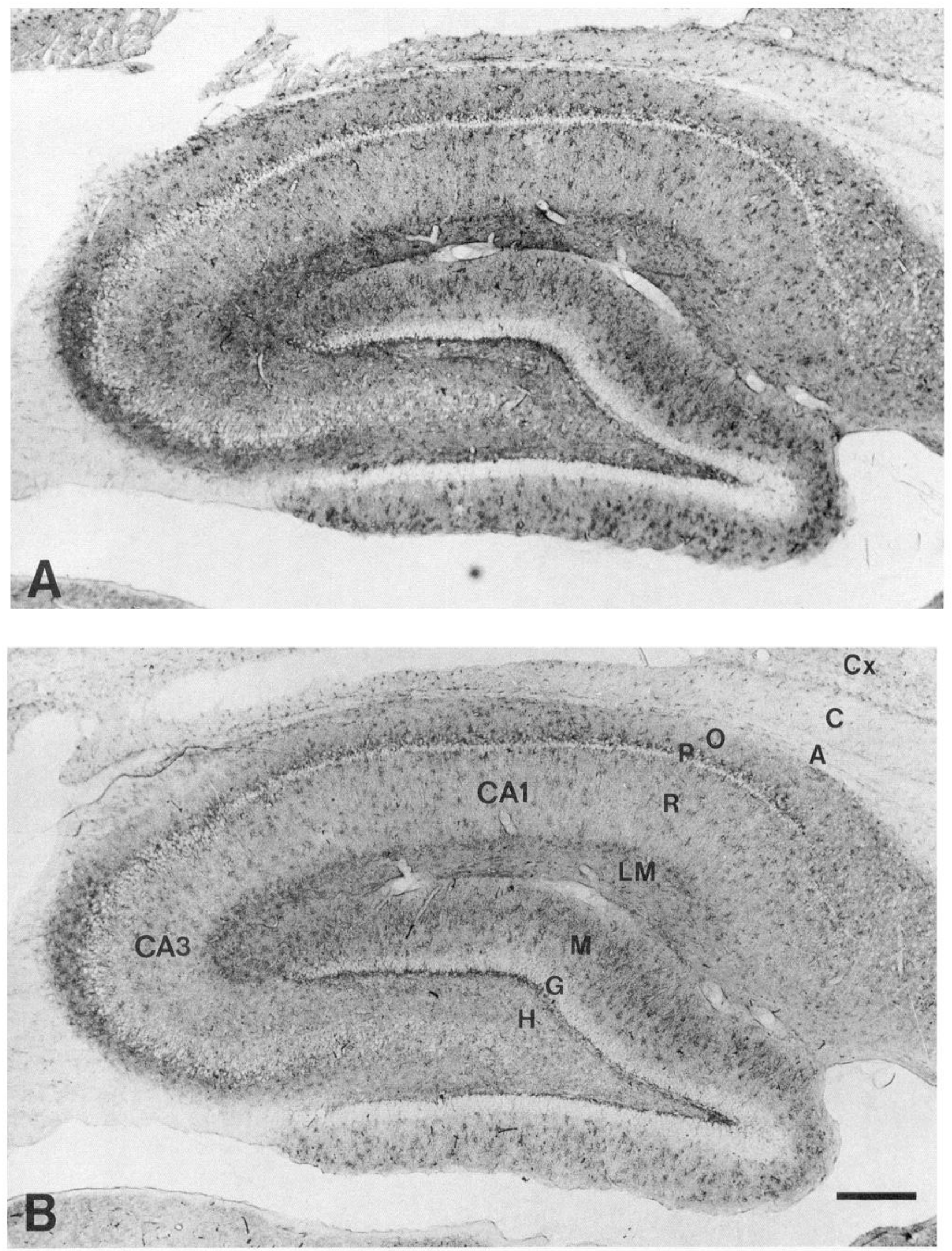

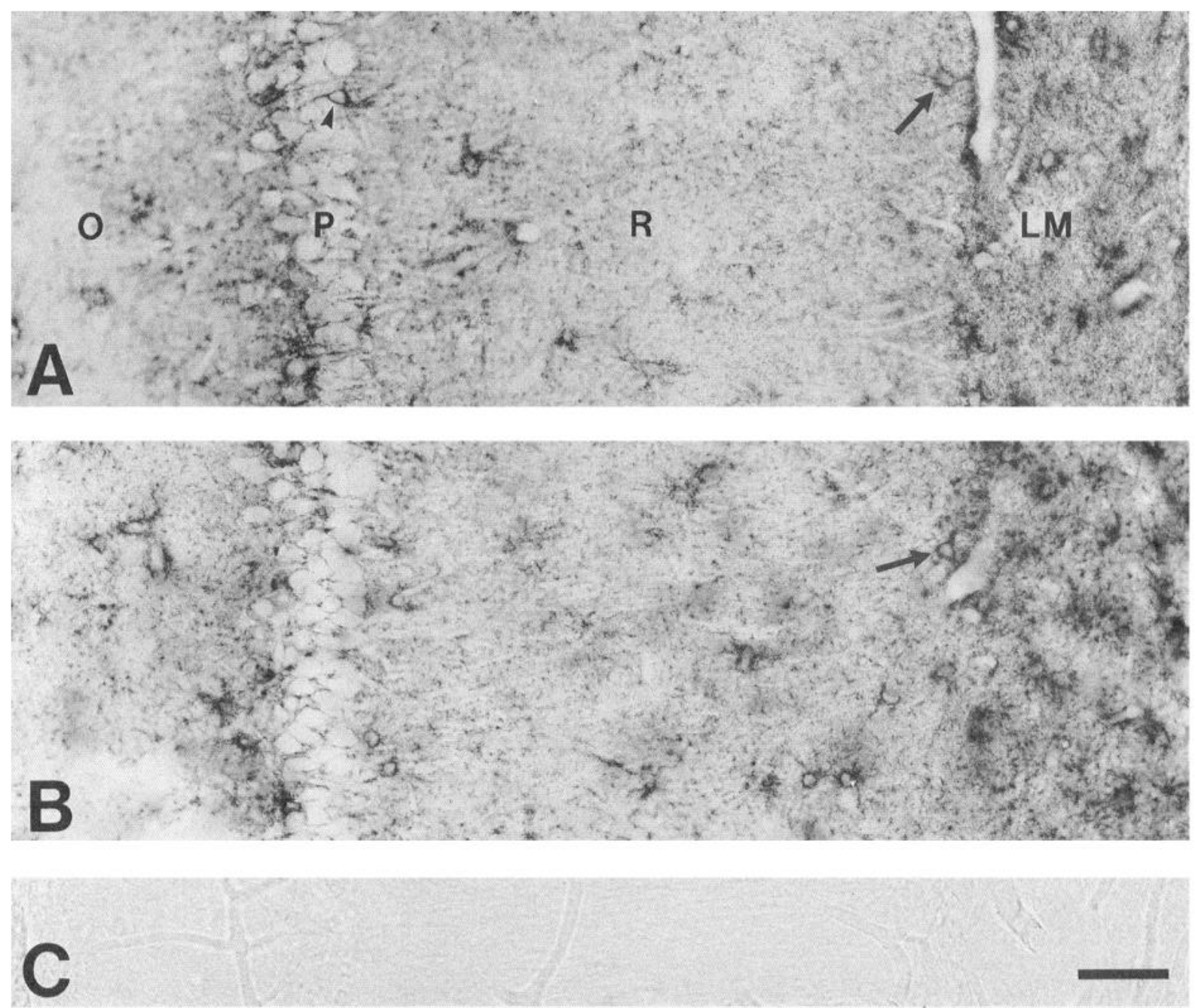

Figure 7. GLT $(A$ and $B)$ and preimmune control $(C)$ in CA1 of hippocampal cortex. Antibodies: $3 \mu \mathrm{g} / \mathrm{ml}$ anti-B2 $(A), 3 \mu \mathrm{g} / \mathrm{ml}$ anti-B12 $(B)$, and $10 \mu \mathrm{g} / \mathrm{ml}$ preimmune IgG $(C)$. Fixatives: $4 \%$ formaldehyde, $0.2 \%$ picric acid, $0.05 \%$ glutaraldehyde $(A$ and $B) ; 2.5 \%$ glutaraldehyde, $1 \%$ formaldehyde $(C)$. Note the similar labeling in the various hippocampal layers with the B2 and B12 antibodies $(A$ and $B)$. The B2 labeling confirms that the translation initiation site of the cloned GLT protein is at the first ATG. Both GLT and GLAST are localized in astrocyte-like cells (arrows) and numerous small processes in the neuropil and between pyramidal cell bodies (arrowhead). Pyramidal cells and dendrites appear negative. $O, P, R$, and $L M$, oriens, pyramidal, radiatum, and lacunosum-moleculare layers. Scale bars, $50 \mu \mathrm{m}$.

does not remove all the immunoreactivity (data not shown). No reactivity (at $500 \mathrm{ng} / \mathrm{ml}$ ) is seen with A494-508 which shows some homology to B493-508 (data not shown).

The antibodies to N-terminal (anti-B12) and C-terminal (antiB493) peptides from the GLT sequence both recognized a relatively broad, apparently heterogeneous band with maximum density at about $73 \mathrm{kDa}$ on immunoblots of crude brain extracts separated by SDS-PAGE (Fig. $2 A$ ). The same staining pattern was obtained with these two peptide directed antibodies as with the affinity purified polyclonal antibody, anti-73 $\mathrm{kDa}$, and the monoclonal antibody, 9C4, raised to the purified glutamate transporter. This band was not recognized by anti-A522, which rec- ognized a similarly wide band at a lower molecular mass, that is, about $66 \mathrm{kDa}$ in cerebellum and slightly lower in other regions (Fig. 2B). Even when the blots were grossly overstained, by increasing the antibody concentrations by a factor of 100 over that needed for detection, no cross-reactivity between GLT and GLAST was detected with the present antibodies. Immunoreactivity for GLT as well as for GLAST was also seen at higher molecular masses, corresponding to the positions expected for dimers and larger aggregates.

Antibodies raised against the peptide $\mathrm{B} 2-11$ recognize a protein of the expected molecular mass on immunoblots and the purified glutamate transporter spotted on filters (and stain glial

Figure 6. GLT $(A)$ and GLAST $(B)$ in the hippocampal formation. Closely spaced sections from an animal perfused with a solution of $4 \%$ formaldehyde, $0.02 \%$ glutaraldehyde were incubated with $0.3 \mu \mathrm{g} / \mathrm{ml}$ anti-B12 $(A)$ or anti-A522 $(B)$ (no Triton). Note that in these conditions the staining intensities and distribution patterns are closely similar for the two proteins. Numerous astrocyte-like cells are stained in white as well as in gray matter. Their density appears highest in LM and superficial parts of $\mathrm{M}$, in a subgranular zone, and in the proximity of the pyramidal layer in CA1. $A, O, P, R$, and $L M$, alveus, oriens, pyramidal, radiatum, and lacunosum-molecular layers of hippocampus; $M, G$, and $H$, molecular, granular, and hilus layers of area dentata; $C$, corpus callosum; $C A 1$ and $C A 3$, subfields of hippocampus; $C x$, cerebral cortex. Scale bar, $300 \mu m$. 



Figure 8. GLT $(A)$, GLAST $(B)$, and preimmune control $(C)$ in parasagittal sections of the cerebellar cortex. Antibodies: $3 \mu \mathrm{g} / \mathrm{ml}$ anti-B12 $(A)$, $0.3 \mu \mathrm{g} / \mathrm{ml} \mathrm{A522}(B)$, and $10 \mu \mathrm{g} / \mathrm{ml}$ preimmune $\operatorname{IgG}(C)$. Fixative: $2.5 \%$ glutaraldehyde, $1 \%$ formaldehyde. Note that, confpared to Figure $6(A$ and $B)$, GLT is weaker and GLAST is much stronger, although the GLT antibody is used at higher concentration. This difference is restricted to the molecular layer, which contains the stained Bergmann glial fibers (arrows) and fine processes (arrowheads). Blood vessels (b) are unstained. The contrast in blood vessel walls in $C$ is due to the use of a narrow iris diaphragm, a single erythrocyte (double arrowhead) shows endogenous peroxidase activity. $\mathrm{Mo}, \mathrm{Pu}$, and $\mathrm{Gr}$, molecular, Purkinje cell and granular layers. Scale bars, $30 \mu \mathrm{m}$.

cells in tissue sections; see below), demonstrating that this initial part of the amino acid sequence exists in the brain.

\section{Separation of glutamate transporters}

Using the glutamate transporter purification procedure (Danbolt et al., 1990, 1992), the starting material (solubilized brain membranes) and the glycoprotein fraction from the lectin column were both immunoreactive with both anti-A522 and anti-B493 antibodies when tested on immunoblots. On the hydroxylapatite column, however, GLT is separated from GLAST. GLT is eluted in a highly purified form with $50 \mathrm{~mm} \mathrm{NaPi}$, while GLAST remains on the column and can be eluted with $500 \mathrm{~mm} \mathrm{NaPi}$ together with most other proteins, including some GLT protein.

\section{Regional immunochemical quantitation}

To quantify the distributions of GLT and GLAST among brain regions (Fig. 3) ${ }^{125} \mathrm{I}$-protein A was used to detect bound anti- bodies on blots similar to those shown in Figure 2. GLT immunoreactivity was strongest in the cerebral cortex, higher in the hippocampal cortex than in the neocortex. The labeling was intermediate in subcortical nuclei (striatum) and brainstem areas, and lowest in the cerebellum. The olfactory bulb was lower in GLT than the brain stem areas, but higher than the cerebellum. The concentration of GLAST, on the other hand, was more than five times higher in the cerebellum than in the cerebral cortical areas. However, similar to GLT, GLAST showed a gradual decline in the rostrocaudal direction. For GLAST as well as for GLT the concentration in the olfactory bulb was intermediate between that in the cerebellum and those in the other areas. It should be emphasized that the data represent relative concentrations among regions and that the absolute amounts of the proteins have not been determined. The mass ratios between GLT and GLAST are therefore not known. 

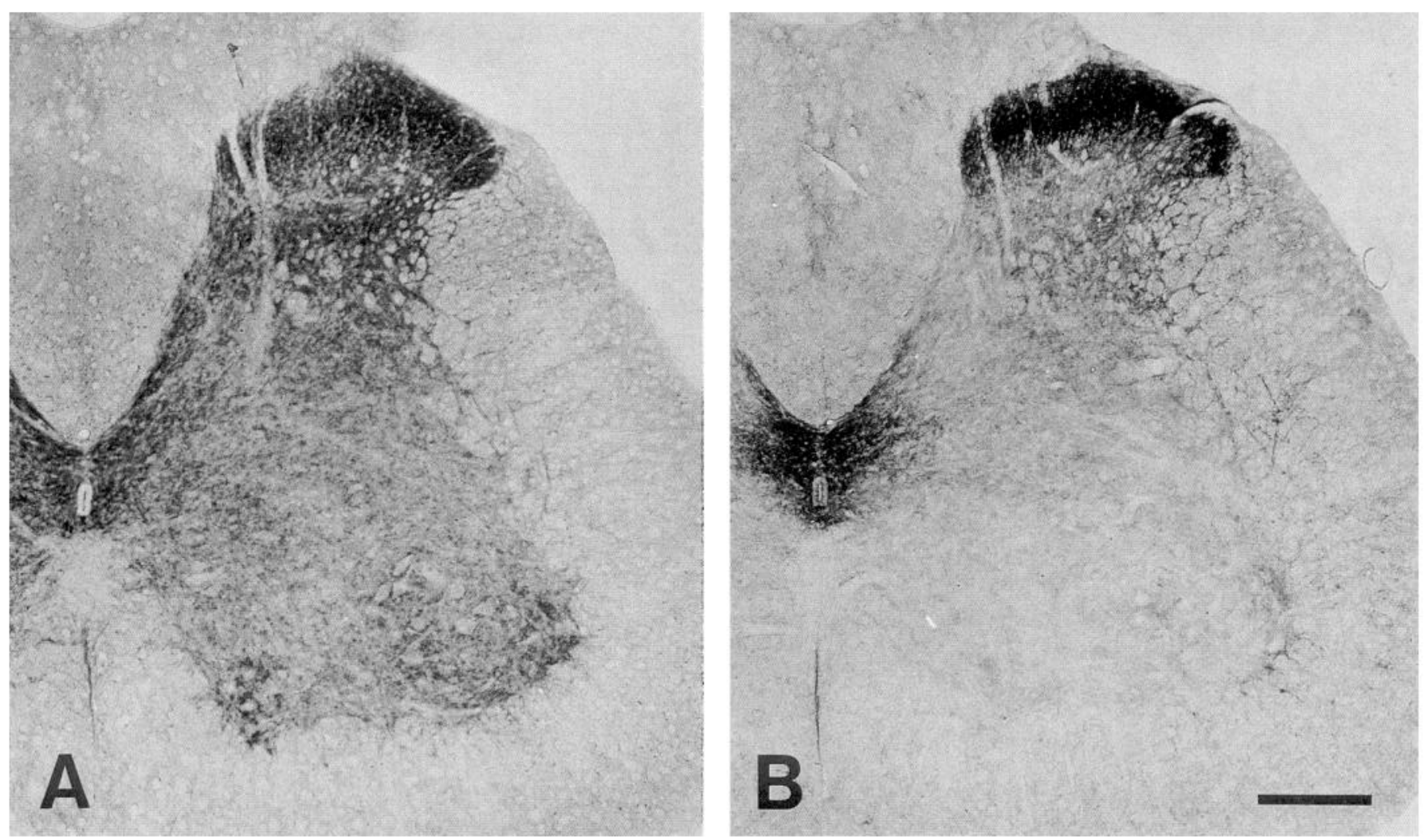

Figure 9. GLT $(A)$ and GLAST $(B)$ in the spinal medulla. Fixative: $4 \%$ formaldehyde, $0.2 \%$ picric acid, $0.05 \%$ glutaraldehyde. Antibodies: $9 \mu \mathrm{g} /$ $\mathrm{ml}$ B493 $(A), 1 \mu \mathrm{g} / \mathrm{ml}$ anti-A522 (B). Note that GLAST and GLT have similar staining intensities in the substantia gelatinosa of the dorsal horn and close to the central canal, but have very different staining intensities in other areas. Staining for GLT is high also in the deep parts of the dorsal horn and in the motor nuclei of the ventral horn. Scale bar, $300 \mu \mathrm{m}$.

\section{Immunocytochemical localization}

Regional distribution. The regional distributions of staining intensities for GLT and GLAST were examined in material treated to have optimal penetration of antibodies, that is, fixation in a medium low in glutaraldehyde, but containing picric acid, and inclusion of Triton X-100 with the antibodies. The differences in the regional distributions of GLT and GLAST revealed by immunocytochemistry (Figs. 4, 5) were in agreement with those determined by quantitative immunochemical analysis (Fig. 3). Thus, GLT was highest in hippocampus and neocortical areas whereas GLAST was highest in the cerebellar cortex. For both proteins the levels in the olfactory bulb were intermediate between those in the cerebellum and other areas, in which the levels of both GLT and GLAST showed a tendency of decline in the rostrocaudal direction. When tissue fixed with high concentrations of glutaraldehyde was processed without Triton X-100 (Figs. 6-10), higher concentrations of the antibodies had to be used and the regional differences were less evident.

The different GLT-specific antibodies, that is, anti-73 kDa (Danbolt et al., 1992), the monoclonal 9C4 (Levy et al., 1993a), anti-B12 and anti-B493, showed the same result. Any apparent minor differences between these antibodies may be ascribed to technical factors, such as the difficulty of matching the antibody concentrations and the sectioning levels.

There was no staining in sections incubated with IgG from preimmune sera (Figs. $7 C, 8 C$ ) or with $\mathrm{IgG}$ remaining in the immune sera after extensive passage through the affinity columns used to isolate the transporter specific antibodies (not shown). When the anti-A3, anti-A522 or anti-B493 antibodies were incubated (1-2 hr) with the corresponding free peptides (10 $\mu \mathrm{g} / \mathrm{ml}, 26 \mu \mathrm{g} / \mathrm{ml}$ or $8 \mu \mathrm{g} / \mathrm{ml}$ respectively) before being applied on the sections, no immunocytochemical staining was observed.

Immunocytochemistry revealed several regional differences and differences between GLT and GLAST that could not be resolved by immunochemical measurement in dissected regions. Thus, in the brainstem both immunoreactivities were high in areas receiving primary afferents (the nucleus of the solitary tract and the substantia gelatinosa of the nucleus of the spinal tract of the trigeminal nerve), whereas the superior olive had staining intensities similar to white matter. Further, the high concentration of GLAST in cerebellum was restricted to the molecular layer of the cerebellar cortex (Figs. 4, 8). Interestingly, the molecular layer of the dorsal cochlear nucleus, which is analogous to the cerebellar molecular layer (Mugnaini et al. 1980), was not higher in GLAST than, for example, the cerebellar granular layer or the cerebellar nuclei (Fig. $4 B$ ). Instead, it was more strongly stained for GLT (Fig. 4A). Within the forebrain, GLAST was higher than average, and high compared to GLT, in layer 1 of the piriform cortex, the lateral septum, the supraoptic and suprachiasmatic nuclei, and the superficial layer of the superior colliculus (Fig. 4B). The same is true of a plexus of stained astrocyte-like cells seen immediately subjacent to the ependyma (not shown). GLT was relatively higher than GLAST in the dorsal part of the lateral geniculate body (Fig. 5G). For both GLT and GLAST the concentrations were higher in the striatum than 

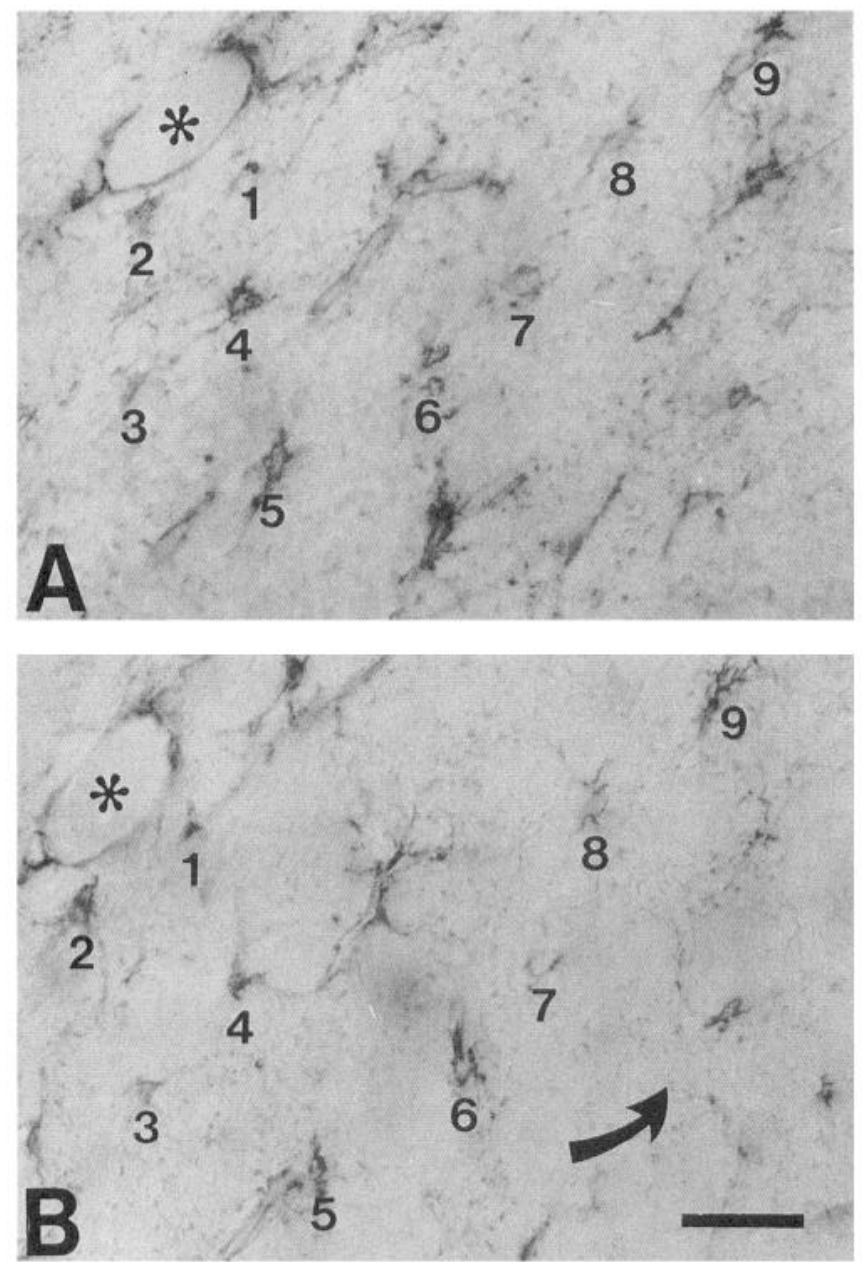

Figure 10. GLT $(A)$ and GLAST $(B)$ in corpus callosum. The complementary surfaces of two adjacent sections were photographed and printed to make the pictures superimposable. Note that the two proteins occur in the same astrocytic cell bodies and processes. Some stained structures (marked by arabic numerals) can be followed from one section to the other. Antibodies: Anti-B12 $0.3 \mu \mathrm{g} / \mathrm{ml}$ or anti-A522 $0.3 \mu \mathrm{g} /$ $\mathrm{ml}$. Fixative: $4 \%$ formaldehyde, $0.02 \%$ glutaraldehyde. Blood vessels $(*)$, serving as landmarks, have perivascular staining due to astrocytic end-feet. Section $B$ was somewhat stretched during mounting (curved arrow). Scale bar, $25 \mu \mathrm{m}$.

in the globus pallidus, a difference which pertained also to the ventral striatum versus the ventral pallidum (Figs. $4 A, B ; 5 C, D$ ). No consistent lamination or regional differences were identified in the cerebral neocortex. Among the regions of white matter, the stria terminalis was the most strongly stained for both proteins (Figs. $4 A, B ; 5 E, F$ ).

Cellular localization. To obtain optimal resolution of structural detail, Triton was omitted, and higher concentrations of glutaraldehyde were used than for studying the regional distribution. Both measures, in particular the absence of Triton, resulted in a generally reduced staining intensity, which could be compensated for by increasing the antibody concentration. When the antibody concentrations were adjusted to give similar staining intensities for GLT and GLAST, principally the same picture was obtained for the two proteins: immunoreactive astrocytelike perikarya and delicate processes occurred in all grey and white matter regions. No other types of structure appeared to be stained. Again, all GLT antibodies gave consistent results.
The immunoreactive structures varied greatly in density. In the hippocampus and neocortex, for example, the stained processes were particularly dense in the neuropil, and much less dense in the white matter. Nevertheless, the staining patterns for GLT and GLAST were essentially the same (Fig. 6). The delicate processes penetrated in between the perikarya of the projection neurons in the pyramidal and granular layers. Their density was higher than average in the zones receiving some categories of glutamatergic afferents, that is, the ones from the entorhinal cortex to stratum lacunosum-moleculare of hippocampus CA1-3 and stratum moleculare of area dentata. The lamination and other intrahippocampal differences (Fig. 6), while consistent between different antibodies, were less clear in Triton exposed material, and may therefore represent differing accessibility of antigenic sites, rather than real differences in transporter protein concentrations.

In sections of the cerebellum, processed at antibody concentrations giving similar staining intensities for GLT and GLAST in the granular layer, staining in the molecular layer was much stronger for GLAST than for GLT (Fig. 8). However, both immunoreactivities appeared to be in the same type of structure, that is, the Bergmann glia.

In the spinal medulla, both GLT and GLAST were highest in the areas receiving primary afferents (like in the brainstem), but the distribution of GLAST was again much more selective than that of GLT (Fig. 9). GLAST was highly concentrated in the dorsal horn (laminae I and II) and in a region close to the central canal. GLT was highest in the same regions, but was distributed throughout the gray matter with an increased density around motor neurons (Fig. 9). For both proteins there was some immunoreactivity in spinal white matter. At high magnification the stained delicate processes could be seen to make a dense network around dendrites and perikarya.

In the subcortical white matter, where individual glial cells are easily discerned, as well as in cortical neuropil, the adjacent surfaces of consecutive sections (Fig. 10) showed the same astrocytes to be stained both for GLT and for GLAST. In view of the results on Western blots (see above), this colocalization cannot be ascribed to cross-reactivity between GLT and GLAST.

Ultrastructural localization. At the ultrastructural level, the GLT-specific and GLAST-specific antibodies all produced the same localization irrespective of the region (Figs. 11-15), although different regions required different concentrations of the two kinds of antibody. Only astrocytes were labeled, processes as well as perikarya. Oligodendrocytes appeared negative, but fibrous astrocytes in white matter were labeled (Fig. 13).

In the hippocampus, labeled astrocytic processes could thus be seen to separate unlabeled pyramidal cell bodies and terminals (Figs. 11, 12), whether anti-73 kDa (Fig. 11A), anti-B493 (Figs. $11 B, 12 B$ ), anti-A522 (Fig. $11 C$ ), or the monoclonal antibody $9 \mathrm{C} 4$ (Fig. 12A,C) were used. In stratum radiatum, terminals with morphological features typical of the glutamatergic Schaffer collaterals were seen adjacent to labeled, delicate astrocytic processes (Fig. 12B). These and other bona fide glutamatergic terminals, for example, terminals with the morphology typical of corticostriatal afferents in the corpus striatum (caudatoputamen) (Fig. 14) and in particular parallel fiber terminals in the cerebellar molecular layer (Fig. 15) were often completely surrounded by immunoreactive astrocytic processes. The glutamatergic nature of the terminals apposed to the immunoreactive glia was supported by the presence of high levels of glutamate in the terminals, as shown by postembedding immunogold la- 


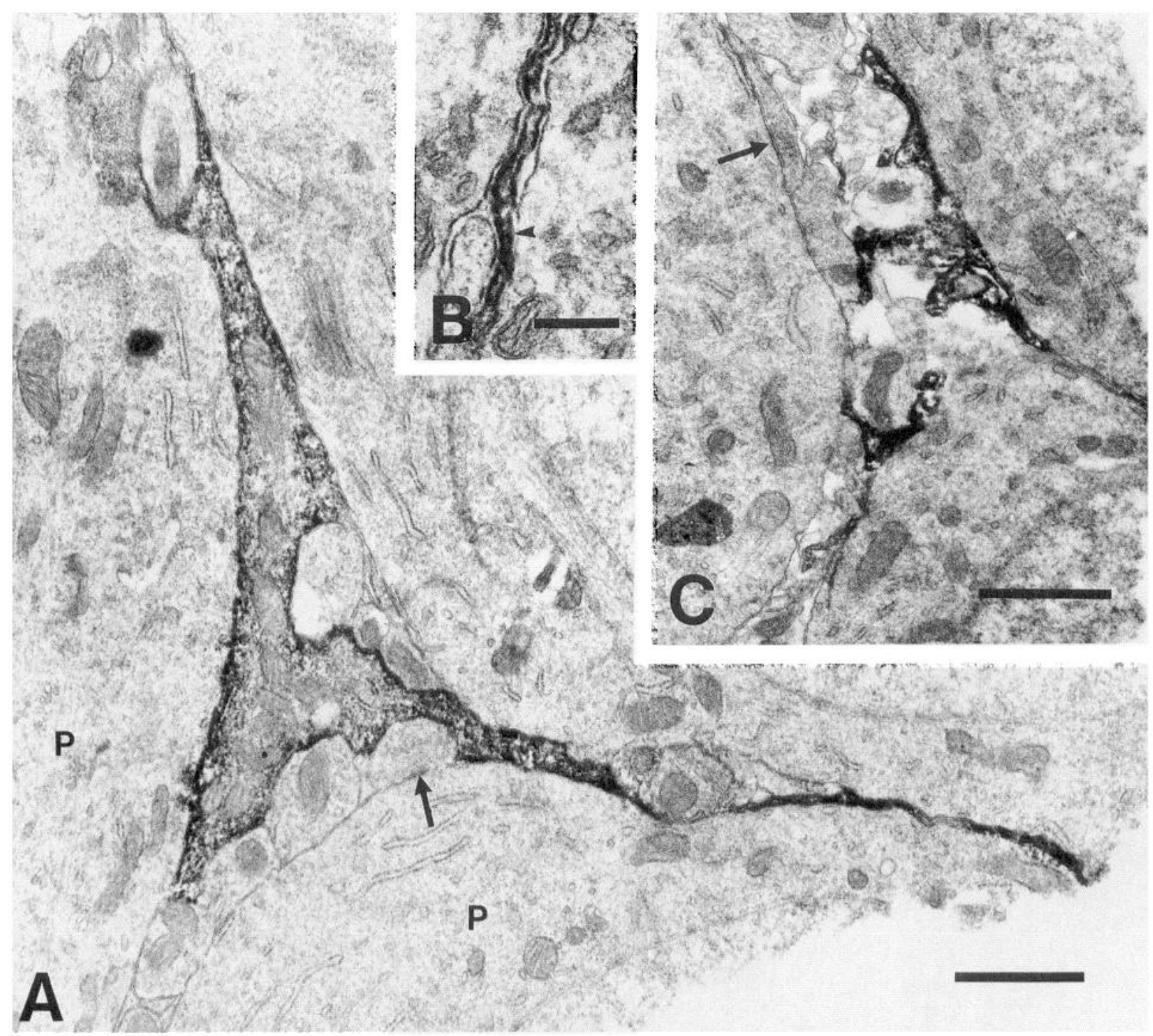

Figure 11. GLT $(A$ and $B)$ and GLAST $(C)$ in astrocytic processes separating pyramidal cell bodies $(P)$ in the pyramidal layer of hippocampus CA1. Note that the staining seems concentrated along the inside of the plasma membrane, and appears to spare the outer membrane layer (arrowhead in $B$ ). The processes surround the glutamatergic neuronal cell bodies as well as likely GABAergic axosomatic nerve terminals (arrows). The pyramidal cell bodies are unstained although opened by the vibratome knife. Antibodies: Anti- $73 \mathrm{kDa} 2.5 \mu \mathrm{g} / \mathrm{ml}(A)$, anti-B493 $6 \mu \mathrm{g} / \mathrm{ml}(B)$, antiA522 $1 \mu \mathrm{g} / \mathrm{ml}(C)$. Fixatives: $2.5 \%$ glutaraldehyde, $1 \%$ formaldehyde $(A$ and $C) ; 4 \%$ formaldehyde, $0.2 \%$ picric acid, $0.05 \%$ glutaraldehyde $(B)$. Scale bars: $A$ and $C, 1 \mu \mathrm{m} ; B, 200 \mathrm{~nm}$.

beling for the amino acid (Fig. 15B). Even nonglutamatergic neurons, such as Purkinje cells (Fig. 15A) and axosomatic boutons (Fig. $11 A, C$ ) could have close contact with GLAST or GLT containing glia.

Though they were adjacent to strongly labeled astrocytic processes, the glutamatergic terminals themselves always appeared completely unlabeled. This was observed independent of the different fixative compositions used and even when the terminals were cut open by the vibratome knife (Fig. 14), suggesting that the failure to stain was not due to a failure of the immunoreagents to penetrate into the axoplasm. The same holds true of glutamatergic perikarya (Fig. 11A,C).

The labeling was entirely intracellular. In moderately reacted preparations the diaminobenzidine reaction product appeared concentrated close to the plasma membrane (Figs. 11A, 12A) sparing its outer lamina (Figs. $11 B, 14$ inset, $15 B$ ), whereas in strongly reacted preparations it filled the cytoplasmic space obscuring the organelles (e.g., Figs. $11 C, 14)$. The extracellular space always was free of reaction product (e.g., Fig. 14). These characteristics were observed with all of the antibodies tested (9C4, anti-73 kDa, - B2, -B12, -B493, - A3, - A522), suggesting that the epitopes of all of these were intracellular. Control experiments (not shown) with peroxidase-labeled wheat germ lectin, which binds to carbohydrate moieties on the cell surface, produced reaction product in the extracellular spaces, confirming that the lack of extracellular staining with the antibodies was real and not due to technical factors.

\section{Discussion}

By means of antibodies to defined parts of the amino and carboxy terminals of two cloned glutamate transporters, GLT and 

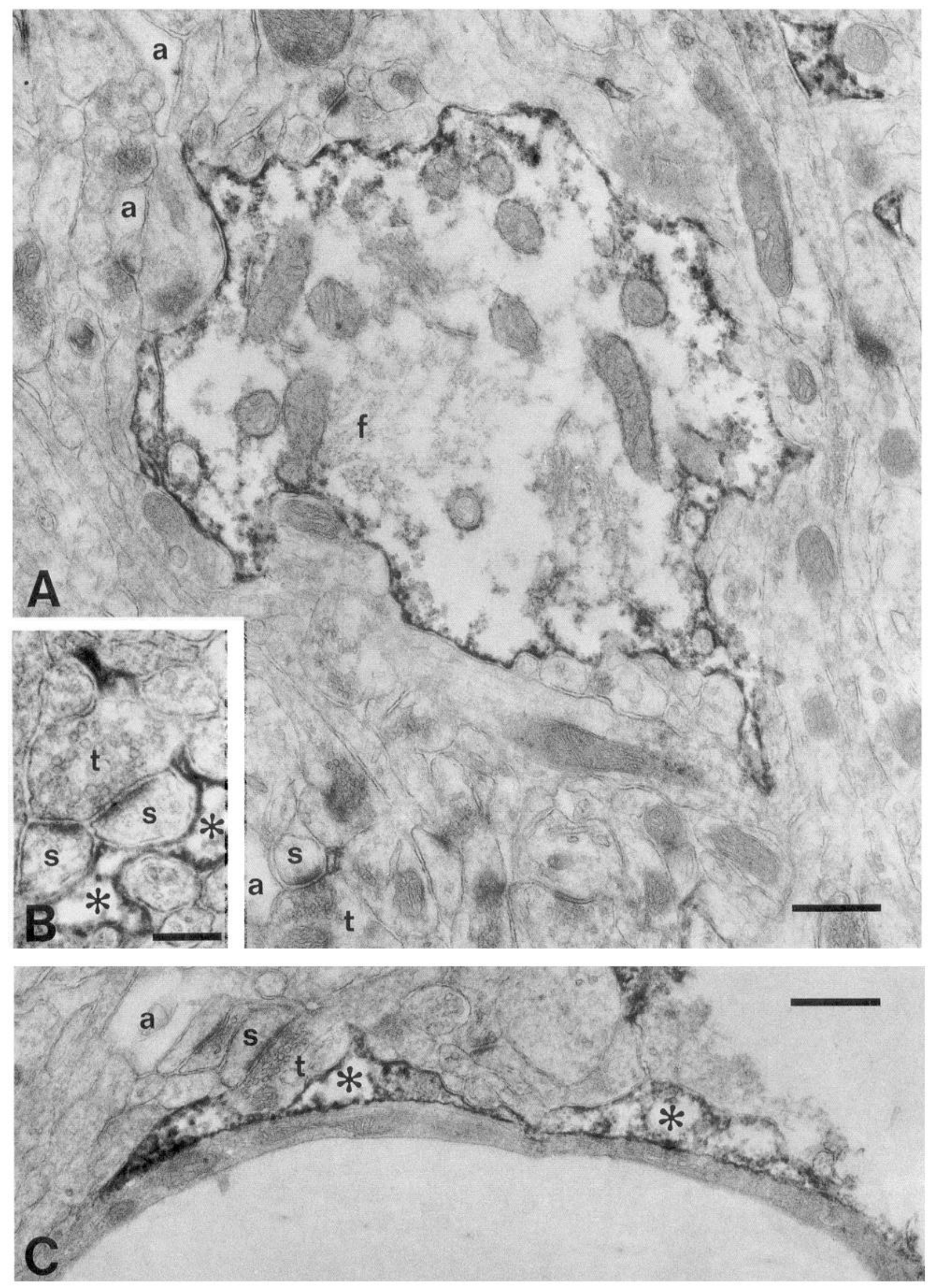




Figure 13. GLAST in fibrous astrocyte in alveus of hippocampus CA1. $n$, Nucleus of astrocyte; arrow, astrocytic filaments; asterisks, reaction product. Antibody: Anti-A522 $1 \mu \mathrm{g} / \mathrm{ml}$. Fixative: $2.5 \%$ glutaraldehyde, $1 \%$ formaldehyde. Scale bar, $1 \mu \mathrm{m}$.

GLAST, we have shown that these two proteins occur in all parts of the CNS, but are differentially distributed.

While the absolute concentrations of GLT and GLAST are still unknown, GLAST has a uniquely high concentration in the cerebellar molecular layer and, is also relatively high, in the olfactory bulb. Within the hemispheres and brainstem, GLT and GLAST show parallel distributions with a rostrocaudal gradient. In these regions the transporter distributions bear resemblance to those of glutamate receptors as revealed by binding of ${ }^{3} \mathrm{H}-$ labeled ligands (Monaghan et al., 1989), or immunocytochemistry with receptor specific antibodies (Petralia and Wenthold, 1992; Martin et al., 1993; Molnár et al., 1993). This is particularly evident in the case of the binding of labeled $\alpha$-amino-3-hydroxy-5-methyl-4-isoxazole propionic acid (AMPA) and is interesting in view of the fact that the moderate glutamate affinity of this receptor type makes it potentially sensitive to changes in glutamate uptake activity (Clements et al., 1992).

Areas of high GLT and/or GLAST immunoreactivity coincide with target areas of dense glutamatergic innervation. Notable examples are hippocampal and other cortical projections, corticofugal pathways (to striatum, colliculi, pons), cerebellar parallel fibers, primary afferents (to the nucleus of the solitary tract and the substantia gelatinosa of the spinal trigeminal nucleus and the spinal gray). On the other hand, some areas thought to be low in glutamatergic innervation (e.g., globus pallidus, ventral pallidum) are also low in GLAST and GLT. These findings are consistent with the view that glutamate transporters are expressed accordingly to the demand for disposing of overflow of glutamate from synapses. In agreement, degeneration of cortical input reduces striatal levels of (the glial) GLT and GLAST (Levy et al., 1993b). Nevertheless some areas that may receive glutamatergic input are conspicuously low in GLT and GLAST (superior olive, parts of midbrain and thalamus). This makes room for the existence of additional glutamate transporters.

Immunocytochemistry clearly showed that both GLAST and GLT are localized in glial cells. The staining of fibrous as well as protoplasmic astrocytes, including the Bergmann glia (Golgi epithelial cells) of the cerebellum, and the apparent lack of staining in oligodendrocytes suggest that GLT as well as GLAST are restricted to astrocytes. The GLT- and GLAST-stained astrocytic processes were often seen to ensheathe axospinous synapses with asymmetric contacts. The apposition to the synaptic cleft represents a favorable position for capturing synaptically released glutamate and for keeping the "tonic" synaptic glutamate concentration low.

No neuronal elements could be identified as immunopositive.

Figure 12. GLT in stratum radiatum of hippocampus CA1. A shows a large stained astrocytic cell process, $B$ small processes $(*)$ adjacent to axospinous synapses, and $C$ perivascular astrocytic foot processes $(*)$. The large process with glial filaments $(f)$ in $A$ is localized at a distance of several micrometers from the section surface, which explains why the higher antibody concentration used gives a moderate staining intensity and why several other glial processes $(a)$ are unlabeled. Note that the staining appears concentrated close to the inside of glial membranes and that axospinous synapses $(s, t)$ are always unlabeled. In this morphological type of synapse the presynaptic terminal $(t)$ as well as the postsynaptic spine $(s)$ belong to putative glutamatergic neurons (CA3 and CA1 pyramidal cells, respectively). $B$ and $C$ are at the surfaces of the vibratome sections. Monoclonal antibody $9 \mathrm{C} 4: 120 \mu \mathrm{g} / \mathrm{ml}(A)$ and $12 \mu \mathrm{g} / \mathrm{ml}(C) . B$, Anti-B493 $6 \mu \mathrm{g} / \mathrm{ml}$. Fixatives: $2.5 \%$ glutaraldehyde, $1 \%$ formaldehyde (A and C); $4 \%$ formaldehyde, $0.2 \%$ picric acid, $0.05 \%$ glutaraldehyde $(B)$. Scale bars: $A$ and $C, 500 \mathrm{~nm} ; B, 200 \mathrm{~nm}$. 
Figure 14. GLT in astrocytic processes $\left({ }^{*}\right)$ ensheathing unstained nerve terminals $(t)$ and dendritic spines $(s)$ in corpus striatum. Anti-B12 $3 \mu \mathrm{g} / \mathrm{ml}$; the section is very lightly contrasted. Fixative: $4 \%$ formaldehyde, $0.2 \%$ picric acid, $0.05 \%$ glutaraldehyde. The terminals, some of which have been torn open by the vibratome knife $\left(t^{\prime}\right)$, have the ultrastructural features typical of corticostriatal terminals, type III (Hassler et al., 1980), which are considered to be glutamatergic. (These features are shown particularly clearly in $\mathrm{t}_{\mathrm{III}}$.) The staining appears not to reach the outer lamina (arrowhead) of the glial plasma membrane (compare Fig. 11B). Scale bars, $200 \mathrm{~nm}$.


These observations included bona fide glutamatergic nerve terminals, such as those of cerebellar parallel fibers, corticostriatal fibers and hippocampal Schaffer collaterals, which have previously been found to take up radiolabeled $(S)$-glutamate and $(R)$ aspartate and contain high concentrations of endogenous glutamate (for review, see Fonnum, 1984). Since glutamatergic nerve terminals are known to be able to take up excitatory amino acids, recently confirmed by immunocytochemistry of exogenous $(R)$ aspartate (Gundersen et al., 1993), this suggests that the neurons contain a different transporter, such as the one cloned from rabbit intestine (Kanai and Hediger, 1992; Kanai et al., 1994). It is also possible that neurons produce GLT or GLAST in low quantities, not detectable by immunocytochemistry.

The peroxidase reaction product was found only intracellularly, indicating that both the amino and carboxy terminals of GLT and GLAST are located on the internal side of the plasma membrane. This implies an even number of transmembrane domains. An even number of transmembrane domains is in agreement with the topologies suggested for GLT (Pines et al., 1992) and GLAST (Storck et al., 1992).

All antibodies to peptides from the GLT sequence gave the same regional and cellular labeling pattern. This was also in agreement with the presently and previously described results with the polyclonal (anti-73 kDa) (Danbolt et al., 1992) and monoclonal (9C4) (Levy et al., 1993a) antibodies raised against the purified transporter from rat brain. A different monoclonal antibody (the clone of which has been lost) also produced astrocytic staining in different brain regions (Hees et al., 1992). Similarly, the antibodies to C- and N-terminal parts of GLAST gave the same localization. These findings confirm the existence in the brain of proteins with the deduced sequences. The finding that anti-B2 antibodies recognize GLT protein in the brain, both in sections and on immunoblots, shows that this epitope is present in the brain and confirms that the translation initiation site is at the first ATG in the sequence of GLT (Pines et al., 1992).

The general immunocytochemical findings are in agreement with the distribution of mRNA for GLT (Torp et al., 1994) and GLAST (Storck et al., 1992; Torp et al., 1994). However, the expression of GLT mRNA (as detected by several oligo cDNA probes, including ones corresponding to the peptide sequences studied in the present paper) in hippocampal CA3 pyramidal cells contrasts with the lack of immunocytochemically detectable GLT protein in the terminals and perikarya of these neurons. This raises the possibility that the production of GLT is posttranscriptionally regulated, and that the CA3 pyramidal cells have a latent ability to produce the protein. The GLAST hy- 

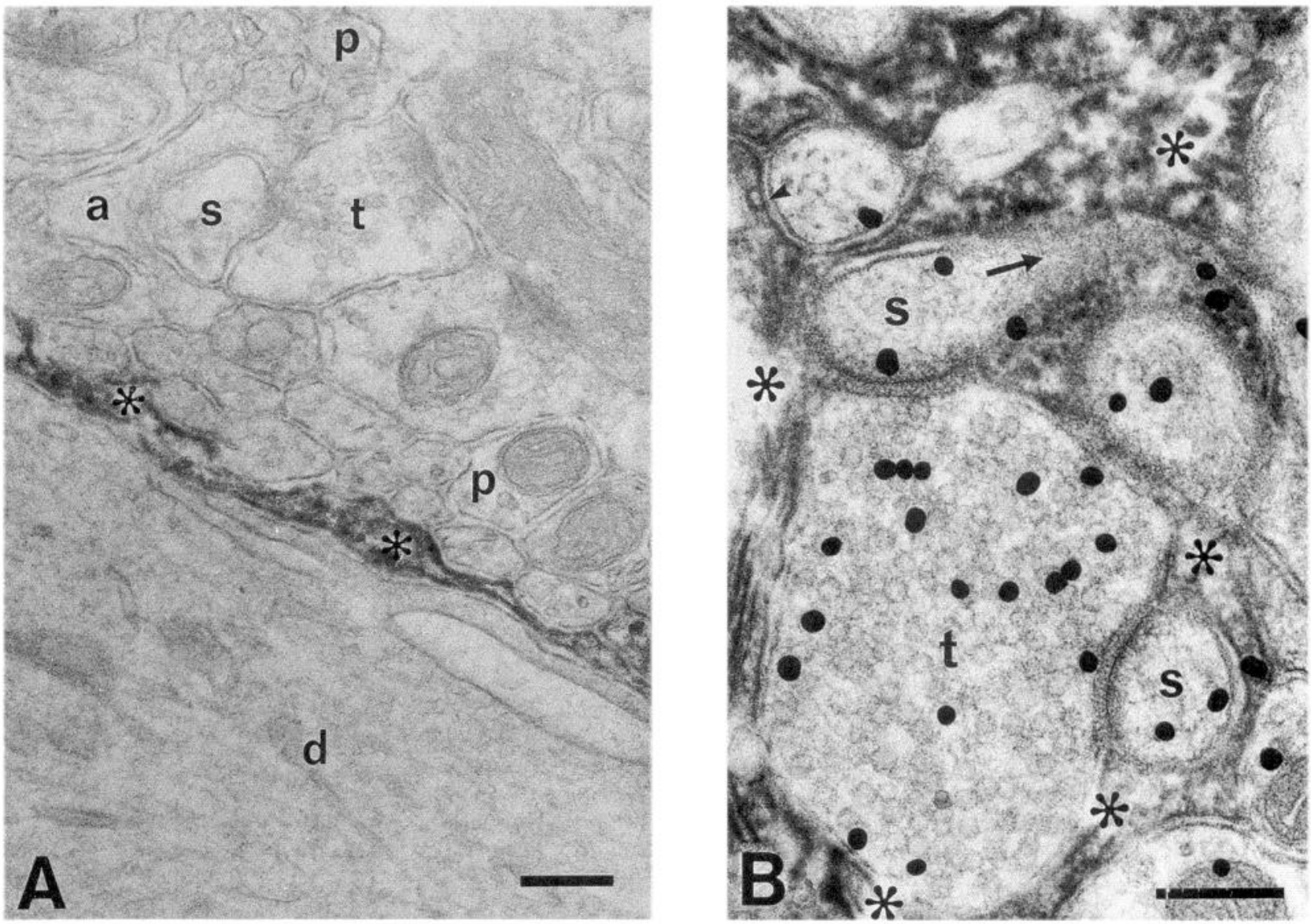

Figure 15. GLT $(A)$ and GLAST $(B)$ in the molecular layer of the cerebellar cortex. (Similar motives can be found for both antibodies.) $A$, GLT in an astroglial process $\left(^{*}\right)$ separating a dendrite $(d)$ from the surrounding neuropil which contains parallel fibers $(p)$, and parallel fiber nerve terminals $(t)$ synapsing on dendritic spines $(s)$. The field is at a distance from the vibratome section surface, consequently some astrocytic processes are unlabeled $(a)$. Anti-B $123 \mu \mathrm{g} / \mathrm{ml}$. Fixative: $4 \%$ formaldehyde, $0.2 \%$ picric acid, $0.05 \%$ glutaraldehyde. $B$, GLAST in astroglial processes (*, partly broken at the vibratome section surface) surrounding a glutamate containing parallel fiber terminal $(t)$ synapsing on two dendritic spines ( $s$ ). The tangentially cut neck of one of the spines is marked by an arrow. Anti-A522 $0.3 \mu \mathrm{g} / \mathrm{ml}$. Fixative: $2.5 \%$ glutaraldehyde, $1 \%$ formaldehyde. The section is immunogold labeled postembedding by antibody to glutaraldehyde-fixed glutamate. Note that the transporter imbued Bergmann glial processes completely enclose the dendrites $(A)$ and the synapses $(B)$; the staining spares the outer lamina of the plasma membrane $($ arrowhead). While glutamate is concentrated in the terminal, other structures also contain some "metabolic" glutamate. [Quantitation in material so processed (Ottersen et al., 1992) has given particle densities of parallel fine boutons about four times those of Purkinje cell dendrites or glia and 70 times background.] Scale bars, $200 \mathrm{~nm}$.

bridization signal along the ventricular wall (Torp et al., 1994) is explained by the present observation of a subependymal GLAST immunoreactive glial plexus.

The present observations that GLT is separated from GLAST during the purification procedure for the $73 \mathrm{kDa}$ transporter (Danbolt et al., 1990, 1992) and that GLAST has higher electrophoretic mobility on SDS-PAGE than GLT explains why the anti-73kDa antiserum contained no antibodies to GLAST. [The purified glutamate transporter protein (Danbolt et al., 1990) was further purified on preparative SDS-PAGE. Only the $73 \mathrm{kDa}$ protein was used for immunization (Danbolt et al., 1992).] All anti-GLT antibodies showed the same staining pattern on immunoblots, different from that shown by the GLAST antibodies. The finding of colocalization of the two immunoreactivities in some regions therefore cannot be ascribed to cross-reactivity.

The proteins, revealed by the peptide specific antibodies, run as broad heterogeneous bands on SDS-PAGE. Potentially, there could be several reasons for this: heterogeneous glycosylation, phosphorylation, random oxidation of the proteins in the polyacrylamide gels, interaction of SH-groups with residual acrylam- ide monomers, etc. Recently, it has been found that there are more than one GLT in the brain (Roginski et al., 1993; O. Gjesdal, M. Bjørås, N. C. Danbolt, and E. Seeberg, unpublished observations). Thus, the reason for the apparent heterogeneity may be that several different, but closely related proteins exist. However, even the cloned GLT and GLAST as well as other cloned transporter proteins such as the noradrenaline transporter (Blakely et al., 1993) and a GABA transporter (Guastella et al., 1990) run as broad bands on SDS-PAGE which may be an effect of their hydrophobic nature. The apparent difference in GLAST molecular mass between cerebellum and other regions remains to be explained.

Our finding that GLT and GLAST occur in the same types of cells suggests the possibility of colocalization in the same cells, which was directly demonstrated in several cases by observing cleaved cells in the complementary surfaces of adjacent sections reacted with different antibodies. This implies that the transporters could exist as heterooligomers. Direct proof pending, it may be inferred that different proportions of the monomers 
could allow great variation in the functional properties of the oligomer.

At least one of the cloned glutamate transporters, GLT (Casado et al., 1993), is regulated by phosphorylation. Arachidonic acid, a retrograde messenger possibly involved in long term potentiation (Bliss and Collinridge, 1993), have been shown to inhibit glutamate transport (Barbour et al., 1989). Regulated expression has been demonstrated for GLT and GLAST (Levy et al., 1993b). We show here that GLT and GLAST are also expressed in the same cells, but in different proportions in different parts of the brain. Because of this and the heterogeneity in transporter proteins referred to above, it may be speculated that the extracellular concentration of excitatory amino acids is carefully regulated and that this regulation is important for brain function. Thus, these transporters may modulate synaptic transmission (Clements et al., 1992). Since glutamatergic overstimulation can give cell damage (McBean and Roberts, 1985; Choi and Rothman, 1990; Choi, 1992) and glutamatergic hypofunction has been implicated in the development of psychosis (Carlsson and Carlsson, 1990; Riederer et al., 1992) and hyperfunction in several psychiatric and neurological disorders (Olney, 1990; Rothstein et al., 1992, 1993; During and Spencer, 1993; Whetsell and Shapira, 1993), the activity of glutamate transporters may not only be important for normal brain function, but also in disease processes.

\section{References}

Arriza JL, Kavanaugh MP, Fairman WA, Wu YN, Murdoch GH, North RA, Amara SG (1993) Cloning and expression of a human neutral amino acid transporter with structural similarity to the glutamate transporter gene family. J Biol Chem 268:15329-15332.

Balcar VI, Johnston GAR (1972) The structural specificity of the high affinity uptake of L-glutamate and L-aspartate by rat brain slices. $\mathbf{J}$ Neurochem 19:2657-2666.

Barbour B, Szatkowski M, Ingledew N, Attwell D (1989) Arachidonic acid induces a prolonged inhibition of glutamate uptake into glial cells. Nature 342:918-920.

Berrebi AS, Mugnaini E (1991) Distribution and targets of the cartwheel cell axon in the dorsal cochlear nucleus of the guinea pig. Anat Embryol 183:427-454.

Blakely RD, Melikian HE, McDonald JK, Gu H, Rudnick G (1993) Characterization of the human norepinephrine transporter with an anti-peptide antibody. Soc Neurosci Abstr 19:494.

Bliss TV, Collingridge GL (1993) A synaptic model of memory: longterm potentiation in the hippocampus. Nature 361:31-39.

Bolton AE, Hunter WM (1973) The labelling of proteins to high specific radioactivities by conjugation to a ${ }^{125} \mathrm{I}$-containing acylating agent. Biochem J 133:529-539.

Briand JP, Muller S, Van Regenmortel MHV (1985) Synthetic peptides as antigens: pitfalls of conjugation methods. J Immunol Methods 78: $59-69$.

Carlsson M, Carlsson A (1990) Interactions between glutamatergic and monoaminergic systems within the basal ganglia-implications for schizophrenia and Parkinson's disease. Trends Neurosci 13:272-276.

Casado M, Bendahan A, Zafra F, Danbolt NC, Aragón C, Giménez C, Kanner BI (1993) Phosphorylation and modulation of brain glutamate transporters by protein kinase C. J Biol Chem, in press.

Choi DW (1992) Excitotoxic cell death. J Neurobiol 23:1261-1276.

Choi DW, Rothman SM (1990) The role of glutamate neurotoxicity in hypoxic-ischemic neuronal death. Annu Rev Neurosci 13:17i-182.

Clements JD, Lester RAJ, Tong G, Jahr CE, Westbrook GL (1992) The time course of glutamate in the synaptic cleft. Science 258:1-1501.

Danbolt NC (1994) The high affinity uptake system for excitatory amino acid neurotransmitters in the brain. Prog Neurobiol, in press.

Danbolt NC, Pines G, Kanner BI (1990) Purification and reconstitution of the sodium- and potassium-coupled glutamate transport glycoprotein from rat brain. Biochemistry 29:6734-6740.

Danbolt NC, Storm-Mathisen J, Kanner BI (1992) A $\left[\mathrm{Na}^{+}+\right.$
$\mathrm{K}^{+} 7$ coupled L-glutamate transporter purified from rat brain is located in glial cell processes. Neuroscience 51:295-310.

Davanger S, Storm-Mathisen J, Ottersen OP (1994) Colocalization of glutamate and glycine in bipolar cell terminals of the human retina. Exp Brain Res 98:342-354

Divac I, Fonnum F, Storm-Mathisen J (1977) High affinity uptake of glutamate in tcrminals of corticostriatal axons. Nature 266:377-378.

During MJ, Spencer DD (1993) Extracellular hippocampal glutamate and spontaneous seizure in the conscious human brain. Lancet 341: $1607-1610$.

Fonnum F (1984) Glutamate: a neurotransmitter in mammalian brain. J Neurochem 42:1-11.

Garthwaite G, Garthwaite J (1988) Electron microscopic autoradiography of $\mathrm{D}-\left[{ }^{3} \mathrm{H}\right]$ aspartate uptake sites in mouse cerebellar slices shows poor labeling of mossy fiber terminals. Brain Res 440:162-166.

Guastella J, Nelson N, Nelson H, Czyzyk L, Keynan S, Miedel MC, Davidson N, Lester HA, Kanner BI (1990) Cloning and expression of a rat brain GABA transporter. Science 249:1303-1306.

Gundersen V, Danbolt NC, Ottersen OP, Storm-Mathisen J (1993) Demonstration of glutamate/aspartate uptake activity in nerve endings by use of antibodies recognizing exogenous D-aspartate. Neuroscience 57:97-111.

Hassler R, Nitsch C, Lee HL (1980) The role of the eight putative transmitters in the nine types of synapses in rat caudate-putamen. In: Parkinson's disease-current progress, problems and management (Rinne UK, Klinger M, Stamm G, eds), pp 61-91. Amsterdam: Elsevier/North-Holland.

Hees B, Danbolt NC, Kanner BI, Haase W, Heitmann K, Koepsell H (1992) A monoclonal antibody against a $\mathrm{Na}^{+}-$L-glutamate cotransporter from rat brain. J Biol Chem 267:23275-23281.

Hjelmeland LM (1980) A nondenaturing zwitterionic detergent for membrane biochemistry: design and synthesis. Proc Natl Acad Sci USA 77:6368-6370.

Johnston GAR (1981) Glutamate uptake and its possible role in neurotransmitter inactivation. In: Glutamate: transmitter in the central nervous system (Roberts PJ, Storm-Mathisen J, Johnston GAR, eds), pp 77-87. Chichester: Wiley.

Kanai Y, Hediger MA (1992) Primary structure and functional characterization of a high-affinity glutamate transporter. Nature 360 :467471.

Kanai Y, Smith CP, Hediger MA (1994) A new family of neurotransmitter transporters: the high-affinity glutamate transporters. FASEB J $8: 1450-1459$.

Kanner BI (1993) Glutamate transporters from brain-a novel neurotransmitter family. FEBS Lett 325:95-99.

Kanner BI, Schuldiner S (1987) Mechanism of transport and storage of neurotransmitters. CRC Crit Rev Biochem 22:1-38.

Laemmli UK (1970) Cleavage of structural proteins during the assembly of the head of bacteriophage T4. Nature 227:680-685.

Levy LM, Lehre KP, Rolstad B, Danbolt NC (1993a) A monoclonal antibody raised against an $\left[\mathrm{Na}^{+}+\mathrm{K}^{+}\right]$coupled L-glutamate transporter purified from rat brain confirms glial cell localization. FEBS Lett 317:79-84.

Levy LM, Lehre KP, Walaas I, Storm-Mathisen J, Danbolt NC (1993b) Down regulation of a glial glutamate transporter in striatum after destruction of the glutamatergic corticostriatal projection. J Neurochem 61:S208.

Logan WJ, Snyder SH (1972) High affinity uptake systems for glycine, glutamic and aspartic acids in synaptosomes of rat central nervous tissues. Brain Res 42:413-431.

Lowry OH, Rosebrough NJ, Farr AL, Randall RJ (1951) Protein measurement with the Folin phenol reagent. J Biol Chem 193:265-275.

Martin LJ, Blackstone CD, Levey AI, Huganir RL, Price DL (1993) AMPA glutamate receptor subunits are differentially distributed in rat brain. Neuroscience 53:327-358.

McBean GJ, Roberts PJ (1985) Neurotoxicity of L-glutamate and DLthreo-3-hydroxyaspartate in the rat striatum. J Neurochem 44:247254.

Molnár E, Baude A, Richmond SA, Patel PB, Somogyi P, McIlhinney AJ (1993) Biochemical and immunocytochemical characterization of antipeptide antibodies to a cloned GluR1 glutamate receptor subunit: cellular and subcellular distribution in the rat forebrain. Neuroscience 53:307-326.

Monaghan DT, Bridges RJ, Cotman CW (1989) The excitatory amino acid receptors: their classes, pharmacology, and distinct properties in 
the function of the central nervous system. Annu Rev Pharmacol Toxicol 29:365-402.

Nicholls D, Attwell D (1990) The release and uptake of excitatory amino acids. Trends Pharmacol Sci 1 1:462-468.

Olney JW (1990) Excitotoxic amino acids and neuropsychiatric disorders. Annu Rev Pharmacol Toxicol 30:47-71.

Ottersen OP, Zhang N, Walberg F (1992) Metabolic compartmentation of glutamate and glutamine: morphological evidence obtained by quantitative immunocytochemistry in rat cerebellum. Neuroscience 46:519-534.

Paxinos G, Watson C (1982) The rat brain in stereotaxic coordinates. Sydney: Academic.

Petralia RS, Wenthold RJ (1992) Light and electron immunocytochemical localization of AMPA-selective glutamate receptors in the rat brain. J Comp Neurol 318:329-354.

Pines G, Danbolt NC, Bjørås M, Zhang Y, Bendahan A, Eide L, Koepsell H, Seeberg E, Storm-Mathisen J, Kanner BI (1992) Cloning and expression of a rat brain L-glutamate transporter. Nature $360: 464$ 467.

Riederer P, Lange KW, Kornhuber J, Danielczyk W (1992) Glutamatergic-dopamincrgic balance in the brain. Its importance in motor disorders and schizophrenia. Arzneimittelforschung 42:265-268.

Roginski R, Choudhury K, Marone M, Geller HM (1993) Molecular cloning and expression of a glutamate transporter cDNA from rat brain. Soc Neurosci Abstr 19:220.

Rothstein JD, Martin LJ, Kuncl RW (1992) Decreased glutamate transport by the brain and spinal cord in amyotrophic lateral sclerosis. $\mathrm{N}$ Engl J Med 326:1464-1468.

Rothstein JD, Jin L, Dykeshoberg M, Kuncl RW (1993) Chronic inhibition of glutamate uptake produces a model of slow neurotoxicity. Proc Natl Acad Sci USA 90:6591-6595.

Schoepp DD, Conn PJ (1993) Metabotropic glutamate receptors in brain function and pathology. Trends Pharmacol Sci 14:13-20.

Schousboe A (1981) Transport and metabolism of glutamate and GABA in neurons and glial cells. Int Rev Neurobiol 22:1-45.
Seeburg PH (1993) The TINS/TiPS lecture-the molecular biology of mammalian glutamate receptor channels. Trends Neurosci 16:359365.

Shafqat S, Tamarappoo BK, Kilberg MS, Puranam RS, McNamara JO, Guadanoferraz A, Fremeau RT (1993) Cloning and expression of a novel $\mathrm{Na}^{+}$-dependent neutral amino acid transporter structurally related to mammalian $\mathrm{Na}^{+}$/glutamate cotransporters. I Biol Chem 268: $15351-15355$.

Somogyi P, Takagi H (1982) A note on the use of picric acid-paraformaldehyde-glutaraldehyde fixative for correlated light and electron microscopic immunocytochemistry. Neuroscience 7:1779-1783.

Storck T, Schulte S, Hofmann K, Stoffel W (1992) Structure, expression, and functional analysis of a $\mathrm{Na}^{+}$-dependent glutamate/aspartate transporter from rat brain. Proc Natl Acad Sci USA 89:10955-10959.

Storm-Mathisen J, Iversen LL (1979) Uptake of [3H]glutamic acid in excitatory nerve endings: light and electron microscopic observations in the hippocampal formation of the rat. Neuroscience 4:1237-1253.

Storm-Mathisen J, Ottersen OP (1990) Immunocytochemistry of glutamate at the synaptic level. J Histochem Cytochem 38:1733-1743.

Taxt T, Storm-Mathisen J (1984) Uptake of D-aspartate and L-glutamate in excitatory axon terminals in hippocampus: autoradiographic and biochemical comparison with gamma-aminobutyrate and other amino acids in normal rats and in rats with lesions. Neuroscience 11:79100.

Torp R, Danbolt NC, Babaie E, Bjørås M, Seeberg E, Storm-Mathisen $J$ and Ottersen OP (1994) Differential expression of two glial glutamate transporters in the rat brain: an in situ hybridization study. Eur J Neurosci 6:936-942.

Towbin H, Staehelin T, Gordon J (1979) Electrophoretic transfer of proteins from polyacrylamide gels to nitrocellulose shects: procedure and some applications. Proc Natl Acad Sci USA 76:4350-4354.

Whetsell WO, Shapira NA (1993) Neuroexcitation, excitotoxicity and hunan neurological disease. Lab Invest 68:372-387.

Wilkin GP, Garthwaite J, Balázs R (1982) Putative acidic amino acid transmitters in the cerebellum. II. Electron microscopic localization of transport sites. Brain Res 244:69-80. 